\title{
A Taxonomy of Operational Cyber Security Risks Version 2
}

\author{
James J. Cebula \\ Mary E. Popeck \\ Lisa R. Young
}

May 2014

TECHNICAL NOTE

CMU/SEI-2014-TN-006

\section{CERT $^{\circledR}$ Division}

Unlimited distribution subject to the copyright.

http://www.sei.cmu.edu

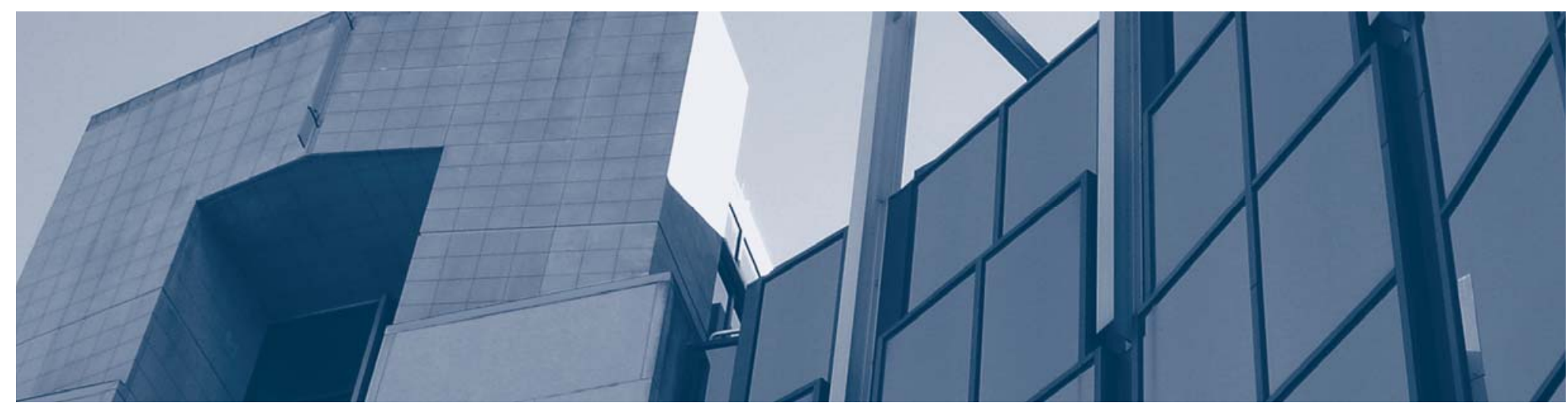

Carnegie Vellon Lniversity 
This material is based upon work funded and supported by DHS DoD under Contract No. FA8721-05C-0003 with Carnegie Mellon University for the operation of the Software Engineering Institute, a federally funded research and development center sponsored by the United States Department of Defense.

Any opinions, findings and conclusions or recommendations expressed in this material are those of the author(s) and do not necessarily reflect the views of DHS DoD or the United States Department of Defense.

This report was prepared for the

SEI Administrative Agent

AFLCMC/PZM

20 Schilling Circle, Bldg 1305, 3rd floor

Hanscom AFB, MA 01731-2125

NO WARRANTY. THIS CARNEGIE MELLON UNIVERSITY AND SOFTWARE ENGINEERING INSTITUTE MATERIAL IS FURNISHED ON AN “AS-IS” BASIS. CARNEGIE MELLON UNIVERSITY MAKES NO WARRANTIES OF ANY KIND, EITHER EXPRESSED OR IMPLIED, AS TO ANY MATTER INCLUDING, BUT NOT LIMITED TO, WARRANTY OF FITNESS FOR PURPOSE OR MERCHANTABILITY, EXCLUSIVITY, OR RESULTS OBTAINED FROM USE OF THE MATERIAL. CARNEGIE MELLON UNIVERSITY DOES NOT MAKE ANY WARRANTY OF ANY KIND WITH RESPECT TO FREEDOM FROM PATENT, TRADEMARK, OR COPYRIGHT INFRINGEMENT.

This material has been approved for public release and unlimited distribution except as restricted below.

Internal use:* Permission to reproduce this material and to prepare derivative works from this material for internal use is granted, provided the copyright and "No Warranty" statements are included with all reproductions and derivative works.

External use:* This material may be reproduced in its entirety, without modification, and freely distributed in written or electronic form without requesting formal permission. Permission is required for any other external and/or commercial use. Requests for permission should be directed to the Software Engineering Institute at permission@sei.cmu.edu.

* These restrictions do not apply to U.S. government entities.

CERT $^{\circledR}$ and OCTAVE ${ }^{\circledR}$ are registered marks of Carnegie Mellon University.

Operationally Critical Threat, Asset, and Vulnerability Evaluation ${ }^{\mathrm{SM}}$

DM-0001337 


\section{Table of Contents}

Abstract vii

$\begin{array}{ll}\text { Introduction } & 1\end{array}$

Taxonomy of Operational Cyber Security Risks $\quad 2$

Class 1 Actions of People 3

Subclass 1.1 Inadvertent 3

Subclass 1.2 Deliberate 4

Subclass 1.3 Inaction 4

Class 2 Systems and Technology Failures 4

Subclass 2.1 Hardware 4

Subclass 2.2 Software 5

Subclass 2.3 Systems

Class 3 Failed Internal Processes 5

Subclass 3.1 Process Design or Execution 5

Subclass 3.2 Process Controls 6

Subclass 3.3 Supporting Processes 6

Class 4 External Events 6

$\begin{array}{ll}\text { Subclass } 4.1 \text { Hazards } & 7\end{array}$

Subclass 4.2 Legal Issues $\quad 7$

Subclass 4.3 Business Issues $\quad 7$

$\begin{array}{ll}\text { Subclass } 4.4 \text { Service Dependencies } & 7\end{array}$

Harmonization with Other Risk Practices $\quad 9$

FISMA $\quad 10$

NIST Special Publications $\quad 10$

SEI OCTAVE Threat Profiles $\quad 11$

$\begin{array}{ll}\text { Conclusion } & 16\end{array}$

Appendix A: Mapping of NIST SP 800-53 Rev. 4 Controls to Selected Taxonomy Subclasses and Elements

Appendix B: Mapping of Selected Taxonomy Subclasses and Elements to NIST SP 800-53 Rev. 4 Controls 
CMU/SEI-2014-TN-006 | ii 


\section{List of Figures}

Figure 1: Relationships Among Assets, Business Processes, and Services [Caralli 2010a] 9

Figure 2: Protection, Sustainability, and Risk [Caralli 2010a] 10

Figure 3: OCTAVE Generic Threat Profile for Human Actors Using Network Access 12

Figure 4: OCTAVE Generic Threat Profile for Human Actors Using Physical Access 13

Figure 5: OCTAVE Generic Threat Profile for System Problems 14

Figure 6: OCTAVE Generic Threat Profile for Other Problems 15 


\section{List of Tables}

Table 1: Taxonomy of Operational Risk 3

Table 2: $\quad$ Mapping of NIST Control Families to Selected Taxonomy Subclasses and Elements 17

Table 3: $\quad$ Mapping of Taxonomy Subclasses and Elements to NIST Controls 30 
CMU/SEI-2014-TN-006 | vi 


\section{Abstract}

This report presents a taxonomy of operational cyber security risks that attempts to identify and organize the sources of operational cyber security risk into four classes: (1) actions of people, (2) systems and technology failures, (3) failed internal processes, and (4) external events. Each class is broken down into subclasses, which are described by their elements. This report discusses the harmonization of the taxonomy with other risk and security activities, particularly those described by the Federal Information Security Management Act (FISMA), the National Institute of Standards and Technology (NIST) Special Publications, and the CERT Operationally Critical Threat, Asset, and Vulnerability Evaluation ${ }^{\mathrm{SM}}\left(\mathrm{OCTAVE}^{\circledR}\right)$ method. 
CMU/SEI-2014-TN-006 | viii 


\section{Introduction}

Organizations of all sizes in both the public and private sectors are increasingly reliant on information and technology assets, supported by people and facility assets, to successfully execute business processes that, in turn, support the delivery of services. Failure of these assets has a direct, negative impact on the business processes they support. This, in turn, can cascade into an inability to deliver services, which ultimately impacts the organizational mission. Given these relationships, the management of risks to these assets is a key factor in positioning the organization for success.

Operational cyber security risks are defined as operational risks to information and technology assets that have consequences affecting the confidentiality, availability, or integrity of information or information systems. This report presents a taxonomy of operational cyber security risks that attempts to identify and organize the sources of operational cyber security risk into four classes: (1) actions of people, (2) systems and technology failures, (3) failed internal processes, and (4) external events. Each class is broken down into subclasses, which are described by their elements. Operational risks are defined as those arising due to the actions of people, systems and technology failures, failed internal processes, and external events. The CERT ${ }^{\circledR}$ Program, part of Carnegie Mellon University's Software Engineering Institute (SEI), developed these four classes of operational risk in the CERT ${ }^{\circledR}$ Resilience Management Model [Caralli 2010b], which draws upon the definition of operational risk adopted by the banking sector in the Basel II framework [BIS 2006]. Within the cyber security space, the risk management focus is primarily on operational risks to information and technology assets. People and facility assets are also considered to the extent that they support information and technology assets.

This taxonomy can be used as a tool to assist in the identification of all applicable operational cyber security risks in an organization. Toward that end, this report also discusses the harmonization of the taxonomy with other risk identification and analysis activities such as those described by the Federal Information Security Management Act of 2002 [FISMA 2002], security guidance contained within the National Institute of Standards and Technology (NIST) Special Publications series, and the threat profile concept contained within the CERT Operationally Critical Threat, Asset, and Vulnerability Evaluation ${ }^{\mathrm{SM}}\left(\mathrm{OCTAVE}^{\circledR}\right)$ method.

This second version of the technical note is an update to the original report (CMU/SEI-2010-TN028) that was published in December 2010. This version provides a taxonomy mapping in Appendices A and B that corresponds with version 4 of NIST SP 800-53.

CERT and OCTAVE are registered marks owned by Carnegie Mellon University.

SM Operationally Critical Threat, Asset, and Vulnerability Evaluation is a service mark of Carnegie Mellon University. 


\section{Taxonomy of Operational Cyber Security Risks}

The taxonomy of operational cyber security risks, summarized in Table 1 and detailed in this section, is structured around a hierarchy of classes, subclasses, and elements. The taxonomy has four main classes:

- actions of people - action, or lack of action, taken by people either deliberately or accidentally that impact cyber security

- $\quad$ systems and technology failures - failure of hardware, software, and information systems

- failed internal processes - problems in the internal business processes that impact the ability to implement, manage, and sustain cyber security, such as process design, execution, and control

- external events - issues often outside the control of the organization, such as disasters, legal issues, business issues, and service provider dependencies

Each of these four classes is further decomposed into subclasses, and each subclass is described by its elements. The structure of this taxonomy is derived from risk taxonomies previously developed by the SEI in the engineered systems operations [Gallagher 2005] and high-performance computing software development [Kendall 2007] subject areas.

Additionally, this taxonomy complements the Department of Homeland Security (DHS) Risk Lexicon [DHS 2008] by describing instances of operational cyber security risks in greater detail. These risks are a small subset of the universe of risks of concern to DHS and covered by its lexicon.

It is important to note that risks can cascade: risks in one class can trigger risks in another class. In this case, the analysis of a particular risk may involve several elements from different classes. For example, a software failure due to improper security settings could be caused by any of the elements of inadvertent or deliberate actions of people. 
Table 1: Taxonomy of Operational Risk

\begin{tabular}{|c|c|c|c|}
\hline 1. Actions of People & $\begin{array}{l}\text { 2. Systems and } \\
\text { Technology Failures }\end{array}$ & $\begin{array}{l}\text { 3. Failed Internal Pro- } \\
\text { cesses }\end{array}$ & 4. External Events \\
\hline $\begin{array}{l}\text { 1.1 Inadvertent } \\
\text { 1.1.1 Mistakes } \\
\text { 1.1.2 Errors } \\
\text { 1.1.3 Omissions } \\
\text { 1.2 Deliberate } \\
\text { 1.2.1 Fraud } \\
\text { 1.2.2 Sabotage } \\
\text { 1.2.3 Theft } \\
\text { 1.2.4 Vandalism } \\
\text { 1.3 Inaction } \\
\text { 1.3.1 Skills } \\
\text { 1.3.2 Knowledge } \\
\text { 1.3.3 Guidance } \\
\text { 1.3.4 Availability }\end{array}$ & $\begin{array}{l}\text { 2.1 Hardware } \\
\text { 2.1.1 Capacity } \\
\text { 2.1.2 Performance } \\
\text { 2.1.3 Maintenance } \\
\text { 2.1.4 Obsolescence } \\
\text { 2.2 Software } \\
\text { 2.2.1 Compatibility } \\
\text { 2.2.2 Configuration } \\
\text { management } \\
\text { 2.2.3 Change control } \\
\text { 2.2.4 Security settings } \\
\text { 2.2.5 Coding practices } \\
\text { 2.2.6 Testing } \\
\text { 2.3 Systems } \\
\text { 2.3.1 Design } \\
\text { 2.3.2 Specifications } \\
\text { 2.3.3 Integration } \\
\text { 2.3.4 Complexity }\end{array}$ & 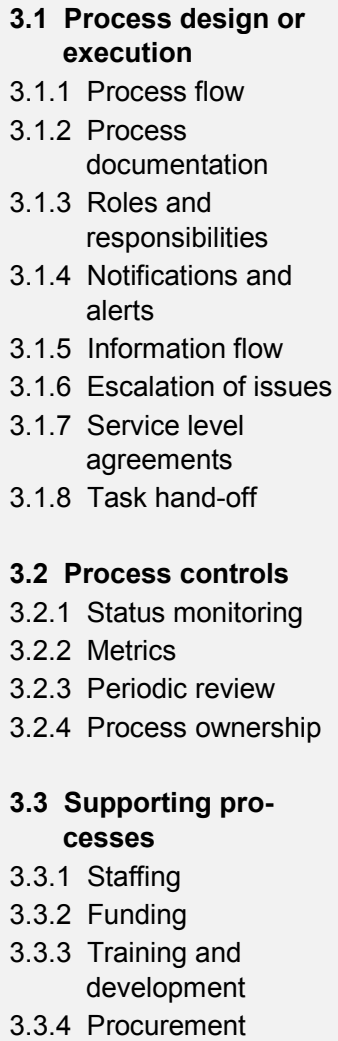 & $\begin{array}{l}\text { 4.1 Disasters } \\
\text { 4.1.1 Weather event } \\
\text { 4.1.2 Fire } \\
\text { 4.1.3 Flood } \\
\text { 4.1.4 Earthquake } \\
\text { 4.1.5 Unrest } \\
\text { 4.1.6 Pandemic } \\
\text { 4.2 Legal issues } \\
\text { 4.2.1 Regulatory compli- } \\
\quad \text { ance } \\
\text { 4.2.2 Legislation } \\
\text { 4.2.3 Litigation } \\
\text { 4.3 Business issues } \\
\text { 4.3.1 Supplier failure } \\
\text { 4.3.2 Market conditions } \\
\text { 4.3.3 Economic } \\
\text { conditions } \\
\text { 4.4 Service } \\
\text { dependencies } \\
\text { 4.4.1 Utilities } \\
\text { 4.4.2 Emergency services } \\
\text { 4.4.3 Fuel } \\
\text { 4.4.4 Transportation }\end{array}$ \\
\hline
\end{tabular}

\section{Class 1 Actions of People}

Actions of people describes a class of operational risk characterized by problems caused by the action taken or not taken by individuals in a given situation. This class covers actions by both insiders and outsiders. Its supporting subclasses include inadvertent actions (generally by insiders), deliberate actions (by insiders or outsiders), and inaction (generally by insiders).

\section{Subclass 1.1 Inadvertent}

The inadvertent subclass refers to unintentional actions taken without malicious or harmful intent. Inadvertent actions are usually, though not exclusively, associated with an individual internal to the organization. This subclass is composed of the elements mistakes, errors, and omissions.

1.1.1 mistake-individual with knowledge of the correct procedure accidentally taking incorrect action

1.1.2 error-individual without knowledge of the correct procedure taking incorrect action

1.1.3 omission -individual not taking a known correct action often due to hasty performance of a procedure 


\section{Subclass 1.2 Deliberate}

The deliberate subclass of actions of people describes actions taken intentionally and with intent to do harm. This subclass is described by the elements fraud, sabotage, theft, and vandalism. Deliberate actions could be carried out by either insiders or outsiders.

1.2.1 fraud-a deliberate action taken to benefit oneself or a collaborator at the expense of the organization

1.2.2 sabotage - a deliberate action taken to cause a failure in an organizational asset or process, generally carried out against targeted key assets by someone possessing or with access to inside knowledge

1.2.3 theft-the intentional, unauthorized taking of organizational assets, in particular information assets 1.2.4 vandalism — the deliberate damaging of organizational assets, often at random

\section{Subclass 1.3 Inaction}

The inaction subclass describes a lack of action or failure to act upon a given situation. Elements of inaction include a failure to act because of a lack of appropriate skills, a lack of knowledge, a lack of guidance, and a lack of availability of the correct person to take action.

1.3.1 skills-an individual's lack of ability to undertake the necessary action

1.3.2 knowledge —an individual's ignorance of the need to take action

1.3.3 guidance - a knowledgeable individual lacking the proper guidance or direction to act

1.3.4 availability — the unavailability or nonexistence of the appropriate resource needed to carry out the action

\section{Class 2 Systems and Technology Failures}

Systems and technology failures describes a class of operational risk characterized by problematic abnormal or unexpected functioning of technology assets. Its supporting subclasses include failures of hardware, software, and integrated systems.

\section{Subclass 2.1 Hardware}

The hardware subclass addresses risks traceable to failures in physical equipment due to capacity, performance, maintenance, and obsolescence.

2.1.1 capacity -inability to handle a given load or volume of information

2.1.2 performance-inability to complete instructions or process information within acceptable parameters (speed, power consumption, heat load, etc.)

2.1.3 maintenance-failure to perform required or recommended upkeep of the equipment

2.1.4 obsolescence-operation of the equipment beyond its supported service life 


\section{Subclass 2.2 Software}

The software subclass addresses risks stemming from software assets of all types, including programs, applications, and operating systems. The elements of software failures are compatibility, configuration management, change control, security settings, coding practices, and testing.

2.2.1 compatibility -inability of two or more pieces of software to work together as expected

2.2.2 configuration management-improper application and management of the appropriate settings and parameters for the intended use

2.2.3 change contro/—changes made to the application or its configuration by a process lacking appropriate authorization, review, and rigor

2.2.4 security settings-improper application of security settings, either too relaxed or too restrictive, within the program or application

2.2.5 coding practices - failures due to programming errors, including syntax and logic problems and failure to follow secure coding practices

2.2.6 testing —inadequate or atypical testing of the software application or configuration

\section{Subclass 2.3 Systems}

The systems subclass deals with failures of integrated systems to perform as expected. Systems failures are described by the elements design, specifications, integration, and complexity.

2.3.1 design-improper fitness of the system for the intended application or use

2.3.2 specifications -improper or inadequate definition of requirements or failure to adhere to the requirements during system construction

2.3.3 integration-failure of various components of the system to function together or interface correctly; also includes inadequate testing of the system

2.3.4 complexity—system intricacy or a large number or interrelationships between components

\section{Class 3 Failed Internal Processes}

Failed internal processes describes a class of operational risk associated with problematic failures of internal processes to perform as needed or expected. Its supporting subclasses include process design or execution, process controls, and supporting processes.

\section{Subclass 3.1 Process Design or Execution}

The process design or execution subclass deals with failures of processes to achieve their desired outcomes due to process design that is improper for the task or due to poor execution of a properly designed process. The elements of process design or execution are process flow, process documentation, roles and responsibilities, notifications and alerts, information flow, escalation of issues, service level agreements, and task hand-off.

3.1.1 process flow-poor design of the movement of process outputs to their intended consumers

3.1.2 process documentation-inadequate documentation of the process inputs, outputs, flow, and stakeholders 
3.1.3 roles and responsibilities_-insufficient definition and understanding of process stakeholder roles and responsibilities

3.1.4 notifications and alerts-inadequate notification regarding a potential process problem or issue

3.1.5 information flow-poor design of the movement of process information to interested parties and stakeholders

3.1.6 escalation of issues-the inadequate or nonexistent ability to escalate abnormal or unexpected conditions for action by appropriate personnel

3.1.7 service level agreements - the lack of agreement among process stakeholders on service expectations that causes a failure to complete expected actions

3.1.8 task hand-off-"dropping the ball" due to the inefficient handing off of a task in progress from one responsible party to another

\section{Subclass 3.2 Process Controls}

The process controls subclass addresses process failures due to inadequate controls on the operation of the process. The elements of this subclass are status monitoring, metrics, periodic review, and process ownership.

3.2.1 status monitoring - failure to review and respond to routine information about the operation of a process

3.2.2 metrics-failure to review process measurements over time for the purpose of determining performance trends

3.2.3 periodic review-failure to review the end-to-end operation of the process on a periodic basis and make any needed changes

3.2.4 process ownership_failure of a process to deliver the expected outcome because of poor definition of its ownership or poor governance practices

\section{Subclass 3.3 Supporting Processes}

The supporting processes subclass deals with operational risks introduced due to failure of organizational supporting processes to deliver the appropriate resources. The supporting processes of concern are the elements staffing, accounting, training and development, and procurement.

3.3.1 staffing-failure to provide appropriate human resources to support its operations

3.3.2 funding - failure to provide appropriate financial resources to support its operations

3.3.3 training and development-Failure to maintain the appropriate skills within the workforce

3.3.4 procurement-failure to provide the proper purchased service and goods necessary to support operations

\section{Class 4 External Events}

External events describes a class of operational risk associated with events generally outside the organization's control. Often the timing or occurrence of such events cannot be planned or predicted. The supporting subclasses of this class include disasters, legal issues, business issues, and service dependencies. 


\section{Subclass 4.1 Hazards}

The hazards subclass deals with risks owing to events, both natural and of human origin, over which the organization has no control and that can occur without notice. The elements supporting this subclass include weather event, fire, flood, earthquake, unrest, and pandemic.

4.1.1 weather event-adverse weather situations such as rain, snow, tornado, or hurricane

4.1.2 fire-fire within a facility or disruption caused by a fire external to a facility

4.1.3 flood-flooding within a facility or disruption caused by a flood external to a facility

4.1.4 earthquake-disruption of organizational operations due to an earthquake

4.1.5 unrest-disruption of operations due to civil disorder, riot, or terrorist acts

4.1.6 pandemic-widespread medical conditions that disrupt organizational operations

\section{Subclass 4.2 Legal Issues}

The legal issues subclass deals with risks potentially impacting the organization due to the elements regulatory compliance, legislation, and litigation.

4.2.1 regulatory compliance-new governmental regulation or failure to comply with existing regulation

4.2.2 legislation-new legislation that impacts the organization

4.2.3 litigation-legal action taken against the organization by any stakeholder, including employees and customers

\section{Subclass 4.3 Business Issues}

The business issues subclass, described by the elements of supplier failure, market conditions, and economic conditions, deals with operational risks arising from changes in the business environment of the organization.

4.3.1 supplier failure - the temporary or permanent inability of a supplier to deliver needed products or services to the organization

4.3.2 market conditions - the diminished ability of the organization to sell its products and services in the market

4.3.3 economic conditions - the inability of the organization to obtain needed funding for its operations

\section{Subclass 4.4 Service Dependencies}

The service dependencies subclass deals with risks arising from the organization's dependence on external parties to continue operations. The subclass is associated with the elements of utilities, emergency services, fuel, and transportation.

4.4.1 utilities-failure of the organization's electric power supply, water supply, or telecommunications services

4.4.2 emergency services-dependencies on public response services such as fire, police, and emergency medical services

4.4.3 fue/—failure of external fuel supplies, for example to power a backup generator 
4.4.4 transportation-failures in external transportation systems, for example, inability of employees to report to work and inability to make and receive deliveries 


\section{Harmonization with Other Risk Practices}

The taxonomy can be used as a tool to help identify all applicable operational cyber security risks in an organization. To provide context and prioritize and manage these risks in a structured manner, a basic understanding of the relationships among assets, business processes, and services needs to be established. Assets are the basic units of value in the organization. There are four primary types of assets: people, information, facilities, and technology. In the cyber security arena, the primary focus is on operational risks to information and technology assets, although people and facility assets are also considered. Assets are the building blocks of business processes. Business processes are the activities that support the organization's delivery of services. The relationships among assets, business processes, and services are shown in Figure 1.

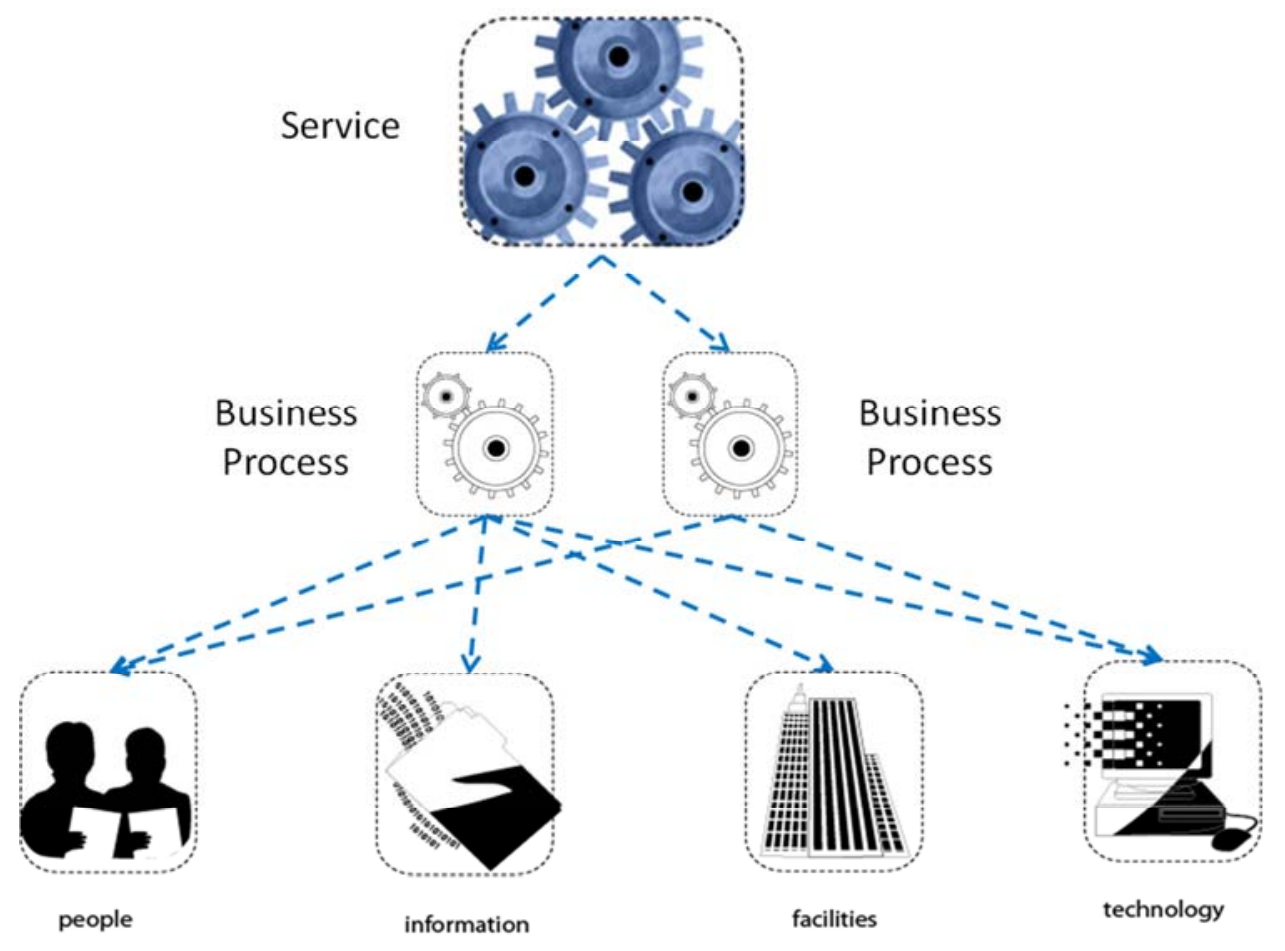

Figure 1: Relationships Among Assets, Business Processes, and Services [Caralli 2010a]

Failure of these assets can have a direct, negative impact on the business processes that they support. This, in turn, cascades into an inability to deliver services and ultimately impacts the mission of the organization. The taxonomy can assist in identifying operational risks in all four classes (actions of people, systems and technology failures, failed internal processes, and external events) to each of the four asset types.

Risk management involves a balance between risk conditions (such as threats and vulnerabilities) and risk consequences. As part of a risk management strategy, protective and sustaining controls are applied to assets, as shown in Figure 2. 


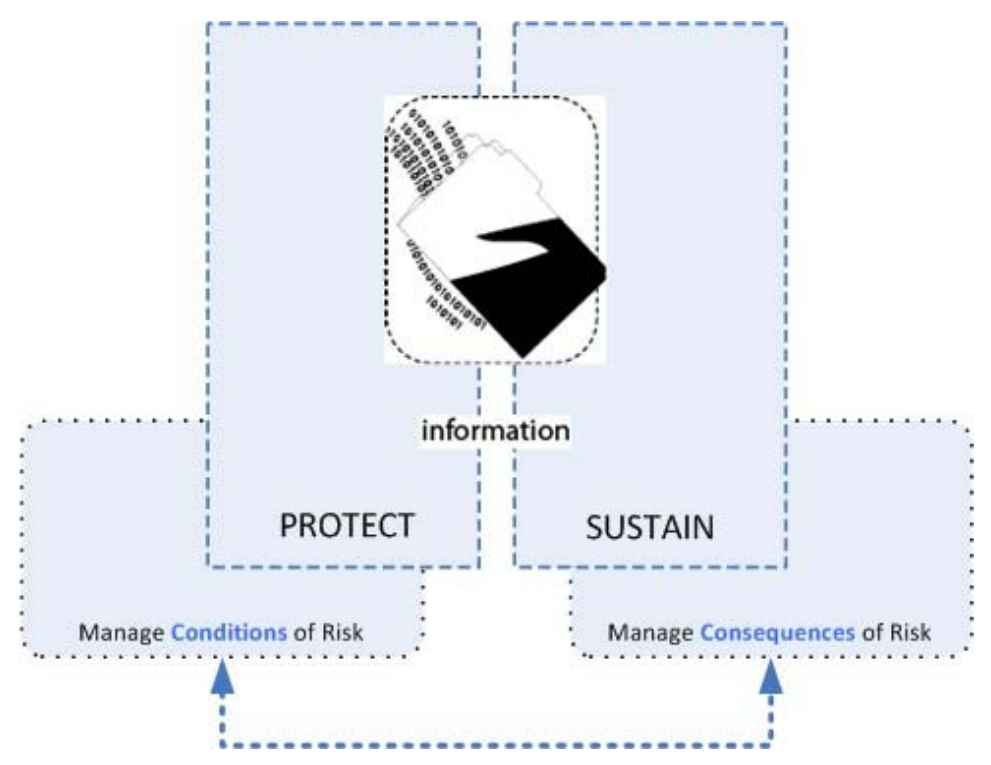

Figure 2: Protection, Sustainability, and Risk [Caralli 2010a]

Protective controls are intended to help manage risk conditions, while sustaining controls are intended to help manage risk consequences. In both cases, controls are applied at the asset level.

\section{FISMA}

The taxonomy provides a structured set of terms that covers all of the significant risk elements that could impact cyber security operations. The Federal Information Security Management Act of 2002 (FISMA), which applies to U.S. federal government agencies, provides a working definition of information security. This definition links the identified operational cyber security risks to specific examples of consequences impacting confidentiality, integrity, and availability. This is an important building block in the control selection and risk mitigation process. The FISMA definition of information security reads as follows:

The term "information security" means protecting information and information systems from unauthorized access, use, disclosure, disruption, modification, or destruction in order to provide-

(A) integrity, which means guarding against improper information modification or destruction, and includes ensuring information non repudiation and authenticity;

(B) confidentiality, which means preserving authorized restrictions on access and disclosure, including means for protecting personal privacy and proprietary information;

and

(C) availability, which means ensuring timely and reliable access to and use of information.

\section{NIST Special Publications}

In addition to providing the definition of information security described above, the FISMA legislation also tasked the National Institute of Standards and Technology (NIST) with developing information security guidelines for use by federal agencies. These guidelines are known as the 
NIST Special Publications (SP). Of particular interest is NIST SP 800-53 rev. 4 [NIST 2013], which provides a control catalog to be applied to federal information systems based on an analysis of the system's relative importance and consequence of loss. The controls specified in NIST SP 800-53 are primarily protective in nature and are applied tactically at the information-system level. In general, the controls specified in NIST SP 800-53 are at a lower level than the elements in the taxonomy. The taxonomy can be used as a tool to link the application of these controls into a broader risk management strategy. A mapping of the control catalog in NIST SP 800-53 rev. 4 to the risk subclasses identified in the taxonomy is provided in Appendix A. This appendix can be used to match NIST control families to types of operational cyber security risk. Appendix B provides the reverse: a mapping of taxonomy subclasses to the NIST SP 800-53 rev. 4 control catalog. Appendix B can be used to determine which NIST controls to consider in order to mitigate specific operational cyber security risks.

\section{SEI OCTAVE Threat Profiles}

The OCTAVE method, developed by the SEI, provides a process for an organization to perform a comprehensive security risk evaluation. Phase 1 of the OCTAVE method uses the concept of asset-based threat profiles. While it is not the intent of this report to provide a detailed discussion of OCTAVE, the threat profiles are introduced here as a useful, graphical vehicle to link assets to risks and consequences, in-line with the definition of operational security risks. OCTAVE uses four standard threat categories: (1) human actors using network access, (2) human actors using physical access, (3) system problems, and (4) other problems. These generic categories can easily be extended or tailored to suit the particular need. In general, the threat categories from OCTAVE align with the classes in the risk taxonomy as follows:

- humans with network access - actions of people class

- $\quad$ humans with physical access - actions of people class

- $\quad$ system problems - systems and technology failures class

- $\quad$ other problems - failed internal processes and external events classes

The threat profiles are represented graphically in a tree structure. Figure 3 through Figure 6 below illustrate the OCTAVE generic threat profiles for the four threat categories. The taxonomy and the techniques described in OCTAVE can serve as cross-checks to each other to ensure coverage of all classes of operational cyber security risk. 


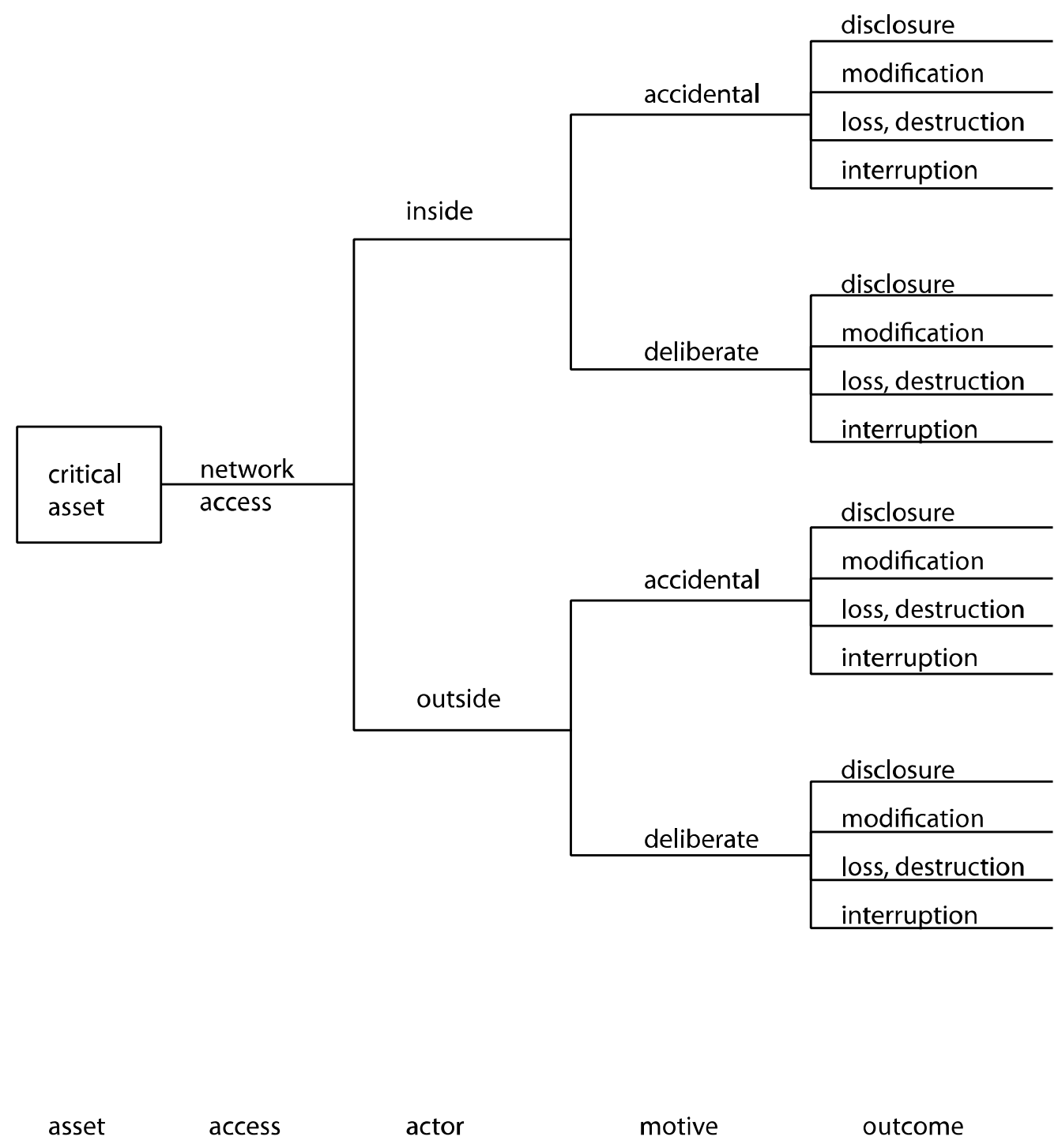

Figure 3: OCTAVE Generic Threat Profile for Human Actors Using Network Access 


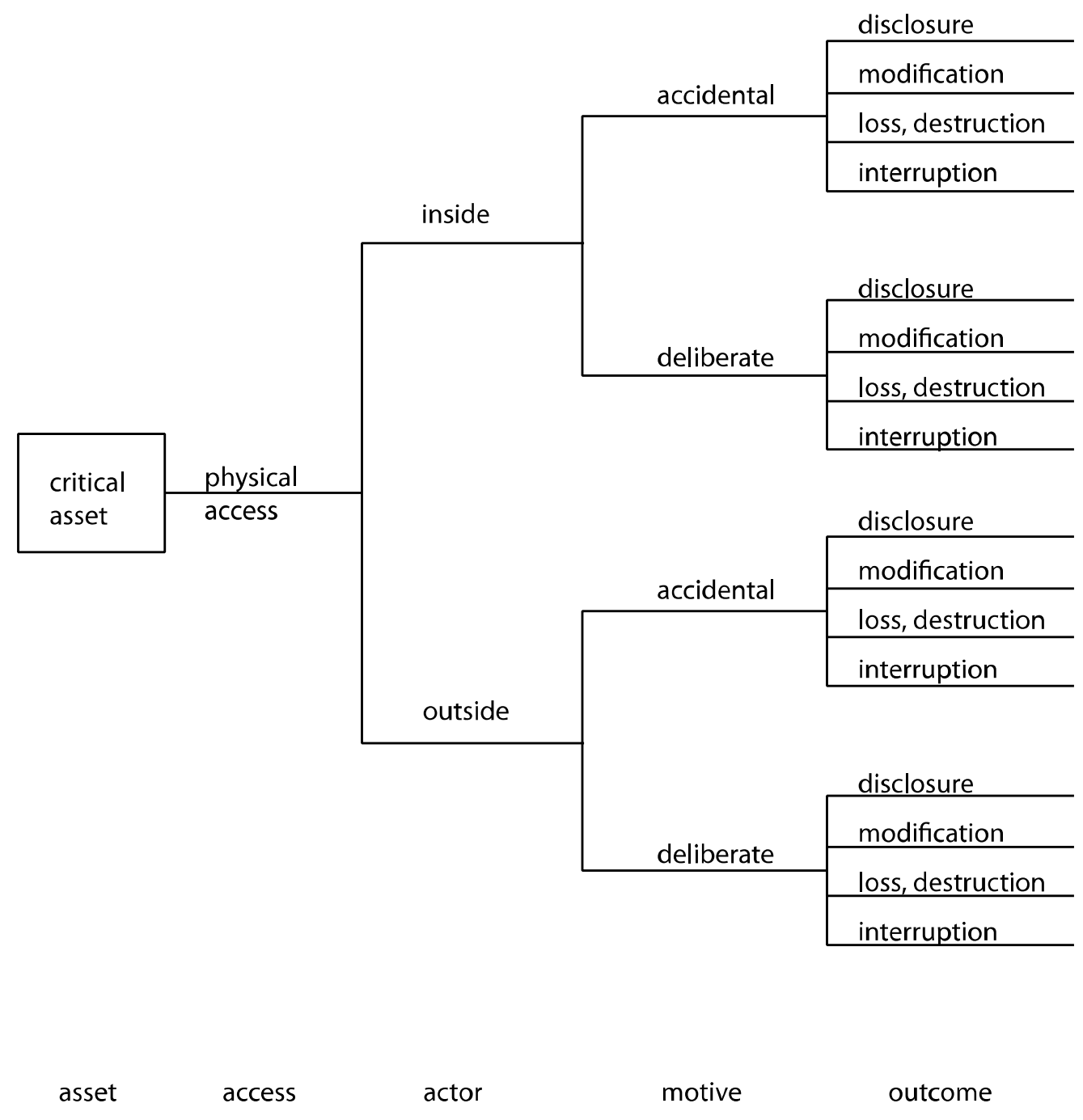

Figure 4: OCTAVE Generic Threat Profile for Human Actors Using Physical Access 


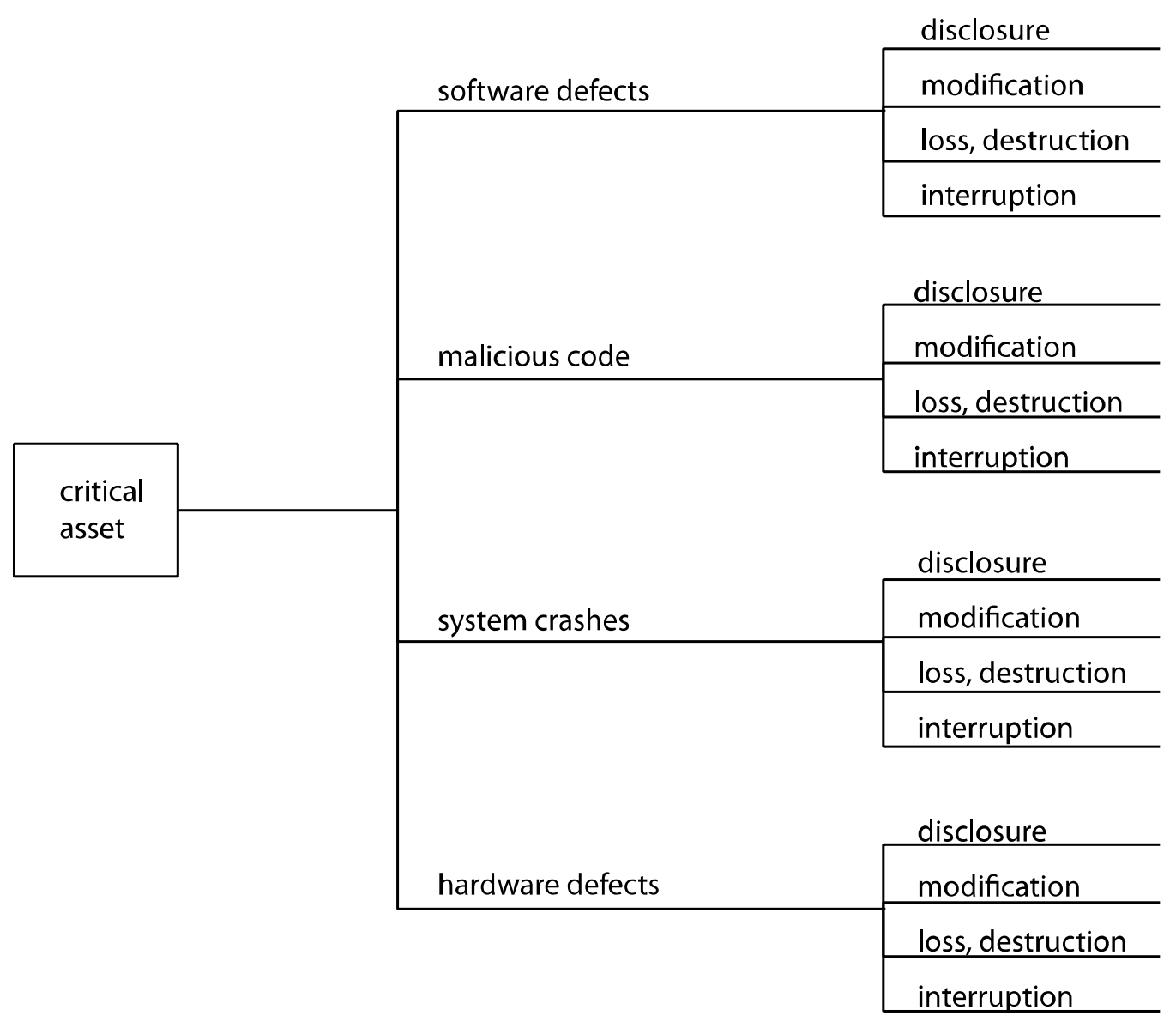

asset

actor

outcome

Figure 5: OCTAVE Generic Threat Profile for System Problems 


\begin{tabular}{|c|c|c|}
\hline & \multirow[b]{2}{*}{ power supply problems } & disclosure \\
\hline \multirow{7}{*}{$\begin{array}{l}\text { critical } \\
\text { asset }\end{array}$} & & modification \\
\hline & \multirow[b]{4}{*}{ telecommunications } & loss, destruction \\
\hline & & interruption \\
\hline & & disclosure \\
\hline & & modification \\
\hline & \multirow[t]{2}{*}{ problems or unavailability } & loss, destruction \\
\hline & & interruption \\
\hline & \multirow[b]{2}{*}{ third-party problems or } & disclosure \\
\hline & & modification \\
\hline & \multirow{2}{*}{$\begin{array}{l}\text { unavailability of } \\
\text { third-party systems }\end{array}$} & loss, destruction \\
\hline & & interruption \\
\hline & \multirow[b]{2}{*}{ natural disasters } & disclosure \\
\hline & & modification \\
\hline & \multirow{2}{*}{$\begin{array}{l}\text { (e.g., flood, fire, } \\
\text { tornado) }\end{array}$} & loss, destruction \\
\hline & & interruption \\
\hline & \multirow[b]{2}{*}{ physical configuration } & disclosure \\
\hline & & modification \\
\hline & \multirow{2}{*}{$\begin{array}{l}\text { or arrangement of } \\
\text { buildings, office, or } \\
\text { equipment }\end{array}$} & loss, destruction \\
\hline & & interruption \\
\hline asset & actor & outcome \\
\hline
\end{tabular}

Figure 6: OCTAVE Generic Threat Profile for Other Problems 


\section{Conclusion}

This report presents a taxonomy of operational cyber security risks and also discusses the relationship of the taxonomy to other risk and security activities. The taxonomy organizes the definition of operational risk into the following four classes: (1) actions of people, (2) systems and technology failures, (3) failed internal processes, and (4) external events. Each of these four classes is further decomposed into subclasses and elements. Operational cyber security risks are defined as operational risks to information and technology assets that have consequences affecting the confidentiality, availability, and integrity of information and information systems. The relationship of operational risks to consequences is discussed in the context of FISMA, the NIST Special Publications, and the OCTAVE method.

We anticipate that revisions to the taxonomy will be necessary to account for changes in the cyber risk landscape. The present taxonomy is being validated through fieldwork with organizations under varying levels of regulatory compliance obligation and risk tolerance. The results of this fieldwork will inform taxonomy revisions. 


\section{Appendix A: Mapping of NIST SP 800-53 Rev. 4 Controls to Selected Taxonomy Subclasses and Elements}

Table 2 can be used to match NIST control families to types of operational cyber security risk.

References to taxonomy subclasses and elements refer to the numbering scheme shown in Table 1 and the body of this report. For example, item 1.1 refers to the subclass inadvertent actions of people (all elements apply), and item 2.2.2 refers to the configuration management element of systems and technology failures - software.

Table 2: $\quad$ Mapping of NIST Control Families to Selected Taxonomy Subclasses and Elements

\begin{tabular}{|c|c|c|}
\hline \multicolumn{2}{|c|}{ NIST SP 800-53 Rev. 4} & \multirow[t]{2}{*}{ Taxonomy Subclasses and Elements } \\
\hline $\begin{array}{l}\text { Control } \\
\text { Number }\end{array}$ & Control Description & \\
\hline$A C-1$ & Access Control Policy and Procedures & 3.1 \\
\hline AC-2 & Account Management & $1.1,1.2,2.2 .2,2.2 .3$ \\
\hline AC-3 & Access Enforcement & $1.1,1.2,2.2,2.3$ \\
\hline AC-4 & Information Flow Enforcement & $1.1,1.2,2.2,2.3$ \\
\hline AC-5 & Separation of Duties & $1.1,1.2,2.2 .2,2.2 .3,2.2 .4,2.3 .2,3.1,3.2$ \\
\hline AC- 6 & Least Privilege & $1.1,1.2,2.2 .2,2.2 .3,2.2 .4,2.3 .2,3.1,3.2$ \\
\hline AC-7 & Unsuccessful Logon Attempts & $1.2,2.2,2.3$ \\
\hline AC-8 & System Use Notification & $2.2,2.3$ \\
\hline AC-9 & Previous Logon (Access) Notification & $1.2,2.2,2.3$ \\
\hline$A C-10$ & Concurrent Session Control & $2.2,2.3$ \\
\hline AC-11 & Session Lock & $2.2,2.3$ \\
\hline AC-12 & Session Termination & $2.2,2.3$ \\
\hline AC-13 & Withdrawn & $N / A$ \\
\hline AC-14 & $\begin{array}{l}\text { Permitted Actions Without Identification or } \\
\text { Authentication }\end{array}$ & $2.3,3.1$ \\
\hline AC-15 & Withdrawn & $N / A$ \\
\hline AC-16 & Security Attributes & $1.1,1.2,2.2,2.3,3.1$ \\
\hline$A C-17$ & Remote Access & $1.2,2.1,2.2,3.1,3.2$ \\
\hline
\end{tabular}




\begin{tabular}{|c|c|c|}
\hline \multicolumn{2}{|c|}{ NIST SP 800-53 Rev. 4} & \multirow[t]{2}{*}{ Taxonomy Subclasses and Elements } \\
\hline $\begin{array}{l}\text { Control } \\
\text { Number }\end{array}$ & Control Description & \\
\hline AC-18 & Wireless Access & $1.2,2.1,2.2,3.1,3.2$ \\
\hline AC-19 & Access Control for Mobile Devices & $1.1,1.2,2.1,2.2,3.1,4.2$ \\
\hline AC-20 & Use of External Information Systems & $1.1,1.2,3.1,4.2,4.3$ \\
\hline AC-21 & Information Sharing & $1.1,1.2,3.1,3.2$ \\
\hline AC-22 & Publicly Accessible Content & $1.1,1,2,3.1,3.2 .3,3.3 .3$ \\
\hline AC-23 & Data Mining Protection & 1.2 \\
\hline AC-24 & Access Control Decisions & $1.1,1.2,3.1$ \\
\hline AC-25 & Reference Monitor & $1.1,1.2,3.1$ \\
\hline AT-1 & $\begin{array}{l}\text { Security Awareness and Training Policy and } \\
\text { Procedures }\end{array}$ & $3.1,3.3 .3$ \\
\hline AT-2 & Security Awareness Training & $1.3 .2,1.3 .3,3.1,3.3 .3$ \\
\hline AT-3 & Role-Based Security Training & $1.3 .1,1.3 .3,3.1,3.3 .3,4.1$ \\
\hline AT-4 & Security Training Records & $1.2,3.1,3.3 .3$ \\
\hline AT-5 & Withdrawn & $N / A$ \\
\hline$A U-1$ & $\begin{array}{l}\text { Audit and Accountability Policy and } \\
\text { Procedures }\end{array}$ & $1.1,1.2,3.2,4.2 .1,4.2 .2$ \\
\hline$A U-2$ & Audit Events & $1.1,1.2,3.1,3.2,4.2 .1,4.2 .2$ \\
\hline$A U-3$ & Content of Audit Records & $1.1,1.2,3.1,3.2$ \\
\hline$A U-4$ & Audit Storage Capacity & 2.1.1 \\
\hline$A U-5$ & Response to Audit Processing Failures & $3.1,3.2$ \\
\hline$A U-6$ & Audit Review, Analysis, and Reporting & 3.2 \\
\hline$A U-7$ & Audit Reduction and Report Generation & $2.3,3.1$ \\
\hline$A U-8$ & Time Stamps & $2.2,2.3$ \\
\hline$A U-9$ & Protection of Audit Information & $1.1,1.2,2.2,2.3,3.1,3.2$ \\
\hline$A U-10$ & Non-Repudiation & $1.1,1.2,2.2,2.3,3.2$ \\
\hline$A U-11$ & Audit Record Retention & $3.1,3.2$ \\
\hline
\end{tabular}




\begin{tabular}{|c|c|c|}
\hline \multicolumn{2}{|c|}{ NIST SP 800-53 Rev. 4} & \multirow[t]{2}{*}{ Taxonomy Subclasses and Elements } \\
\hline $\begin{array}{l}\text { Control } \\
\text { Number }\end{array}$ & Control Description & \\
\hline $\mathrm{AU}-12$ & Audit Generation & $2.2,2.3,3.1$ \\
\hline$A U-13$ & Monitoring for Information Disclosure & $1.1,1.2,3.1,3.2,4.2$ \\
\hline $\mathrm{AU}-14$ & Session Audit & $2.2,2.3$ \\
\hline$A U-15$ & Alternate Audit Capability & 2.3 \\
\hline$A U-16$ & Cross-Organizational Auditing & $1.1,1.2,3.1$ \\
\hline CA-1 & $\begin{array}{l}\text { Security Assessment and Authorization } \\
\text { Policies and Procedures }\end{array}$ & $1.1,1.2,3.1,3.2$ \\
\hline CA-2 & Security Assessments & $1.1,1.2,3.1,3.2$ \\
\hline CA-3 & System Connections & $1.1,1.2,3.1,4.2$ \\
\hline CA-4 & Withdrawn & $N / A$ \\
\hline CA-5 & Plan of Action and Milestones & $1.3 .4,3.1,3.2,3.3,4.2 .1$ \\
\hline CA- 6 & Security Authorization & $3.1,3.2$ \\
\hline CA-7 & Continuous Monitoring & $2.2,2.3,3.2$ \\
\hline CA-8 & Penetration Testing & $2.2 .4,2.2 .6,2.3 .3$ \\
\hline CA-9 & Internal System Connections & $2.2,2.3,3.1$ \\
\hline CM-1 & $\begin{array}{l}\text { Configuration Management Policy and } \\
\text { Procedures }\end{array}$ & $2.2 .2,2.2 .3,2.2 .4,3.1,3.2$ \\
\hline CM-2 & Baseline Configuration & $2.2 .2,2.2 .3,2.2 .4,3.1,3.2$ \\
\hline $\mathrm{CM}-3$ & Configuration Change Control & $2.2 .2,2.2 .3,2.2 .4,3.1,3.2$ \\
\hline CM-4 & Security Impact Analysis & $2.2 .2,2.2 .3,2.2 .4,2.2 .5,2.3,3.1$ \\
\hline CM-5 & Access Restrictions for Change & $1.1,1.2,2.2 .2,2.2 .3,2.2 .4,2.2 .5,3.1$ \\
\hline CM-6 & Configuration Settings & $2.2 .2,2.2 .3,2.2 .4,3.1,3.2$ \\
\hline $\mathrm{CM}-7$ & Least Functionality & $1.1,1.2,2.2,2.3,3.1,3.2$ \\
\hline CM-8 & Information System Component Inventory & $2.1,2.2,2.3,3.1$ \\
\hline CM-9 & Configuration Management Plan & $2.2 .2,2.3,3.1$ \\
\hline CM-10 & Software Usage Restrictions & $1.1,1.2,2.2 .2,3.1,4.2$ \\
\hline
\end{tabular}




\begin{tabular}{|c|c|c|}
\hline \multicolumn{2}{|c|}{ NIST SP 800-53 Rev. 4} & \multirow[t]{2}{*}{ Taxonomy Subclasses and Elements } \\
\hline $\begin{array}{l}\text { Control } \\
\text { Number }\end{array}$ & Control Description & \\
\hline $\mathrm{CM}-11$ & User-Installed Software & $1.1,1.2,2.2 .3,3.1,4.2$ \\
\hline $\mathrm{CP}-1$ & $\begin{array}{l}\text { Contingency Planning Policy and } \\
\text { Procedures }\end{array}$ & $3.1,3.2,4.1,4.3,4.4$ \\
\hline $\mathrm{CP}-2$ & Contingency Plan & $1.1,1.2,1.3,3.3,4.1,4.2,4.3,4.4$ \\
\hline CP-3 & Contingency Training & $1.3,3.3 .3,4.1,4.4$ \\
\hline $\mathrm{CP}-4$ & Contingency Plan Testing & $1.3,3.1,3.3 .3,4.1,4.2,4.3,4.4$ \\
\hline CP-5 & Withdrawn & $N / A$ \\
\hline CP-6 & Alternate Storage Site & $2.1,2.2,2.3,4.1,4.3,4.4$ \\
\hline CP-7 & Alternate Processing Site & $2.1,2.2,2.3,4.1,4.3,4.4$ \\
\hline CP-8 & Telecommunications Services & $2.1,2.2,2.3,3.3,4.1,4.2,4.3,4.4$ \\
\hline CP-9 & Information System Backup & $1.1,1.2,2.2,2.3,3.1,4.1,4.4$ \\
\hline CP-10 & $\begin{array}{l}\text { Information System Recovery and } \\
\text { Reconstitution }\end{array}$ & $3.1,4.1,4.2,4.3,4.4$ \\
\hline $\mathrm{CP}-11$ & Alternate Communications Protocols & $2.2,2.3,3.1$ \\
\hline $\mathrm{CP}-12$ & Safe Mode & $1.2,2.1,2.3,4.1,4.4$ \\
\hline CP-13 & Alternate Security Mechanisms & $1.2,2.2,2.3,4.1,4.4$ \\
\hline $\mathrm{IA}-1$ & $\begin{array}{l}\text { Identification and Authentication Policy and } \\
\text { Procedures }\end{array}$ & $1.1,1.2,2.2,2.3,3.1,3.2$ \\
\hline $\mid A-2$ & $\begin{array}{l}\text { Identification and Authentication } \\
\text { (Organizational Users) }\end{array}$ & $1.1,1.2,2.2,2.3,3.1,3.2$ \\
\hline IA-3 & Device Identification and Authentication & $1.1,1.2,2.1,2.3,3.1,3.2$ \\
\hline $\mathrm{IA}-4$ & Identifier Management & $1.1,1.2,2.2,2.3,3.1,3.2$ \\
\hline IA-5 & Authenticator Management & $1.1,1.2,2.2,2.3,3.1,3.2$ \\
\hline IA-6 & Authenticator Feedback & $1.1,1.2,2.2,2.3,3.1,3.2$ \\
\hline IA-7 & Cryptographic Module Authentication & $1.1,1.2,2.2,2.3,3.1,3.2,4.2$ \\
\hline $\mathrm{IA}-8$ & $\begin{array}{l}\text { Identification and Authentication } \\
\text { (Non-Organizational Users) }\end{array}$ & $1.1,1.2,2.2,2.3,3.1,3.2,4.2,4.3$ \\
\hline
\end{tabular}




\begin{tabular}{|c|c|c|}
\hline \multicolumn{2}{|c|}{ NIST SP 800-53 Rev. 4} & \multirow[t]{2}{*}{ Taxonomy Subclasses and Elements } \\
\hline $\begin{array}{l}\text { Control } \\
\text { Number }\end{array}$ & Control Description & \\
\hline IA-9 & Service Identification and Authentication & $1.1,1.2,2.2,2.3,3.1,3.2,4.3$ \\
\hline $\mathrm{IA}-10$ & Adaptive Identification and Authentication & 1.2 \\
\hline $\mid A-11$ & Re-Authentication & $1.1,1.2$ \\
\hline IR-1 & Incident Response Policy and Procedures & $1.1,1.2,1.3,3.1,3.2$ \\
\hline IR-2 & Incident Response Training & $1.3,3.3 .3$ \\
\hline IR-3 & Incident Response Testing & $1.1,1.2,1.3,3.1,3.2$ \\
\hline IR-4 & Incident Handling & $1.1,1.2,1.3,3.1,3.2$ \\
\hline IR-5 & Incident Monitoring & $1.1,1.2,1.3,3.1,3.2$ \\
\hline IR-6 & Incident Reporting & $1.1,1.2,1.3,3.1,3.2 .4 .2$ \\
\hline IR-7 & Incident Response Assistance & $1.1,1.2,1.3,3.1,3.2$ \\
\hline IR-8 & Incident Response Plan & $1.1,1.2,1.3,3.1,3.2$ \\
\hline IR-9 & Information Spillage Response & $1.1,1.2,1.3,3.1,3.2,4.2$ \\
\hline IR-10 & $\begin{array}{l}\text { Integrated Information Security Analysis } \\
\text { Team }\end{array}$ & $1.1,1.2,1.3,3.1,3.2$ \\
\hline MA-1 & System Maintenance Policy and Procedures & $2.1 .3,2.3,3.1,3.2$ \\
\hline MA-2 & Controlled Maintenance & $1.1,1.3,2.1 .3,2.3,3.1,3.2,3.3$ \\
\hline MA-3 & Maintenance Tools & $1.1,1.2,1.3,2.1 .3,2.3,3.1,3.2,3.3$ \\
\hline MA-4 & Non-Local Maintenance & $1.1,1.2,1.3,2.1 .3,2.3,3.1,3.2,3.3$ \\
\hline MA-5 & Maintenance Personnel & $1.1,1.2,1.3,2.1 .3,2.3,3.1,3.2,3.3,4.3$ \\
\hline MA-6 & Timely Maintenance & $1.1,1.2,1.3,2.1 .3,2.3,3.1,3.2,3.3$ \\
\hline MP-1 & Media Protection Policy and Procedures & $1.1,1.2,2.1,2.2,3.1,3.2,4.2$ \\
\hline MP-2 & Media Access & $1.1,1.2,2.1,2.2,3.1,3.2,4.2$ \\
\hline MP-3 & Media Marking & $1.1,1.2,2.1,2.2,3.1,3.2,4.2$ \\
\hline MP-4 & Media Storage & $1.1,1.2,2.1,2.2,3.1,3.2,4.2$ \\
\hline MP-5 & Media Transport & $1.1,1.2,2.1,2.2,3.1,3.2,4.2$ \\
\hline
\end{tabular}




\begin{tabular}{|c|c|c|}
\hline \multicolumn{2}{|c|}{ NIST SP 800-53 Rev. 4} & \multirow[t]{2}{*}{ Taxonomy Subclasses and Elements } \\
\hline $\begin{array}{l}\text { Control } \\
\text { Number }\end{array}$ & Control Description & \\
\hline MP-6 & Media Sanitization & $1.1,1.2,2.1,2.2,3.1,3.2,4.2$ \\
\hline MP-7 & Media Use & $1.1,1.2,2.1,2.2,3.1,3.2,4.2$ \\
\hline MP-8 & Media Downgrading & $1.1,1.2,2.1,2.2,3.1,3.2,4.2$ \\
\hline PE-1 & $\begin{array}{l}\text { Physical and Environmental Protection } \\
\text { Policy and Procedures }\end{array}$ & $1.1,1.2,3.1,3.2,4.2$ \\
\hline PE-2 & Physical Access Authorizations & $1.1,1.2,3.1,3.2,4.2$ \\
\hline PE-3 & Physical Access Control & $1.1,1.2,3.1,3.2,4.2$ \\
\hline $\mathrm{PE}-4$ & Access Control for Transmission Medium & $1.1,1.2,3.1,3.2$ \\
\hline PE-5 & Access Control for Output Devices & $1.1,1.2,3.1,3.2$ \\
\hline PE-6 & Monitoring Physical Access & $1.1,1.2,3.1,3.2$ \\
\hline $\mathrm{PE}-7$ & Withdrawn & $N / A$ \\
\hline PE-8 & Visitor Access Records & $1.1,1.2,3.1,3.2$ \\
\hline PE-9 & Power Equipment and Cabling & $1.1,1.2,3.1,3.2$ \\
\hline PE-10 & Emergency Shutoff & $1.1,1.2,3.1,3.2,4.1,4.4$ \\
\hline PE-11 & Emergency Power & $1.1,1.2,3.1,3.2,4.1,4.4$ \\
\hline $\mathrm{PE}-12$ & Emergency Lighting & $1.1,1.2,3.1,3.2,4.1,4.4$ \\
\hline $\mathrm{PE}-13$ & Fire Protection & $1.1,1.2,3.1,3.2,4.1 .2,4.4$ \\
\hline PE-14 & Temperature and Humidity Controls & $1.1,1.2,2.1,3.1,3.2$ \\
\hline PE-15 & Water Damage Protection & $1.1,1.2,3.1,3.2,4.1 .3,4.4$ \\
\hline PE-16 & Delivery and Removal & $1.1,1.2,3.1,3.2$ \\
\hline $\mathrm{PE}-17$ & Alternate Work Site & $1.1,1.2,3.1,3.2,4.1,4.4$ \\
\hline $\mathrm{PE}-18$ & Location of Information System Components & $1.1,1.2,3.1,3.2,4.1,4.4$ \\
\hline PE-19 & Information Leakage & $1.1,1.2,3.1,3.2,4.2$ \\
\hline PE-20 & Asset Monitoring and Tracking & $1.1,1.2,3.1,3.2,4.2$ \\
\hline PL-1 & Security Planning Policy and Procedures & $3.1,3.2,3.3$ \\
\hline
\end{tabular}




\begin{tabular}{|c|c|c|}
\hline \multicolumn{2}{|c|}{ NIST SP 800-53 Rev. 4} & \multirow[t]{2}{*}{ Taxonomy Subclasses and Elements } \\
\hline $\begin{array}{l}\text { Control } \\
\text { Number }\end{array}$ & Control Description & \\
\hline PL-2 & System Security Plan & $3.1,3.2,3.3$ \\
\hline PL-3 & Withdrawn & $N / A$ \\
\hline PL-4 & Rules of Behavior & $1.1,1.2,1.3,3.2,3.3 .3$ \\
\hline PL-5 & Withdrawn & $N / A$ \\
\hline PL-6 & Withdrawn & $N / A$ \\
\hline PL-7 & Security Concept of Operations & $3.1,3.2$ \\
\hline PL-8 & Information Security Architecture & $2.1,2.2,2.3,3.2$ \\
\hline PL-9 & Central Management & $3.1,3.2$ \\
\hline PS-1 & Personnel Security Policy and Procedures & $1.1,1.2,1.3,3.3 .3,4.2$ \\
\hline PS-2 & Position Risk Designation & $1.1,1.2,1.3,3.3 .3,4.2$ \\
\hline PS-3 & Personnel Screening & $1.1,1.2,1.3,3.3 .3,4.2$ \\
\hline PS-4 & Personnel Termination & $1.1,1.2,1.3,4.2$ \\
\hline PS-5 & Personnel Transfer & $1.1,1.2,1.3,4.2$ \\
\hline PS-6 & Access Agreements & $1.1,1.2,1.3,3.1,3.2,3.3 .3,4.2$ \\
\hline PS-7 & Third-Party Personnel Security & $1.1,1.2,1.3,3.1,3.2,3.3 .3,4.3$ \\
\hline PS-8 & Personnel Sanctions & $1.1,1.2,1.3,3.1,4.2$ \\
\hline RA-1 & Risk Assessment Policy and Procedures & $3.1,3.2$ \\
\hline RA-2 & Security Categorization & $3.1,3.2,4.2,4.3$ \\
\hline RA-3 & Risk Assessment & $3.1,3.2,4.2,4.3$ \\
\hline RA-4 & Withdrawn & $N / A$ \\
\hline RA-5 & Vulnerability Scanning & $1.1,1.2,1.3,2.2 .4,3.1,3.2$ \\
\hline RA-6 & $\begin{array}{l}\text { Technical Surveillance Countermeasures } \\
\text { Survey }\end{array}$ & $1.1,1.2,1.3,2.2 .4$ \\
\hline SA-1 & $\begin{array}{l}\text { System and Services Acquisition Policy and } \\
\text { Procedures }\end{array}$ & $2.3,3.1,3.2,3.3 .4,4.4$ \\
\hline SA-2 & Allocation of Resources & $2.1,2.2,2.3,3.3,4.2,4.3$ \\
\hline
\end{tabular}




\begin{tabular}{|c|c|c|}
\hline \multicolumn{2}{|c|}{ NIST SP 800-53 Rev. 4} & \multirow[t]{2}{*}{ Taxonomy Subclasses and Elements } \\
\hline $\begin{array}{l}\text { Control } \\
\text { Number }\end{array}$ & Control Description & \\
\hline SA-3 & System Development Life Cycle & $2.1,2.2,2.3,3.3,4.2,4.3$ \\
\hline SA-4 & Acquisition Process & $2.3,3.3 .4,4.4$ \\
\hline SA-5 & Information System Documentation & $2.1,2.2,2.3,3.3,4.2,4.3$ \\
\hline SA-6 & Withdrawn & $N / A$ \\
\hline SA-7 & Withdrawn & $N / A$ \\
\hline SA-8 & Security Engineering Principles & $2.1,2.2,2.3$ \\
\hline SA-9 & External Information System Services & $2.1,2.2,2.3,3.3,4.2,4.3$ \\
\hline SA-10 & Developer Configuration Management & $2.1,2.2,2.3,3.3,4.2,4.3$ \\
\hline SA-11 & Developer Security Testing and Evaluation & $2.1,2.2,2.3,3.3,4.2,4.3$ \\
\hline SA-12 & Supply Chain Protection & $2.1,2.2,2.3,3.3,4.2,4.3$ \\
\hline SA-13 & Trustworthiness & $2.1,2.2,2.3,3.3,4.2,4.3$ \\
\hline SA-14 & Criticality Analysis & $2.1,2.2,2.3,3.3,4.2,4.3$ \\
\hline SA-15 & $\begin{array}{l}\text { Development Process, Standards, and } \\
\text { Tools }\end{array}$ & $2.1,2.2,2.3,3.3,4.2,4.3$ \\
\hline SA-16 & Developer-Provided Training & $1.3,3.3 .3,4.2,4.3$ \\
\hline SA-17 & Developer Security Architecture and Design & $2.1,2.2,2.3,3.3,4.2,4.3$ \\
\hline SA-18 & Tamper Resistance and Detection & $1.1,1.2,2.1,2.2,2.3$ \\
\hline SA-19 & Component Authenticity & $1.1,1.2,1.3,3.1,3.2,3.3 .3$ \\
\hline SA-20 & $\begin{array}{l}\text { Customized Development of Critical Com- } \\
\text { ponents }\end{array}$ & $1.2,2.2 .4$ \\
\hline SA-21 & Developer Screening & $1.2,4.2$ \\
\hline SA-22 & Unsupported System Components & $2.1 .3,2.1 .4,4.3$ \\
\hline SC-1 & $\begin{array}{l}\text { System and Communications Protection } \\
\text { Policy and Procedures }\end{array}$ & $3.1,3.2,4.2$ \\
\hline SC-2 & Application Partitioning & $1.1,1.2$ \\
\hline SC-3 & Security Function Isolation & $1.1,1.2,2.2,2.3$ \\
\hline
\end{tabular}




\begin{tabular}{|c|c|c|}
\hline \multicolumn{2}{|c|}{ NIST SP 800-53 Rev. 4} & \multirow[t]{2}{*}{ Taxonomy Subclasses and Elements } \\
\hline $\begin{array}{l}\text { Control } \\
\text { Number }\end{array}$ & Control Description & \\
\hline SC-4 & Information In Shared Resources & $1.1,1.2,2.2,2.3$ \\
\hline SC-5 & Denial of Service Protection & $1.2,2.1,2.2,2.3$ \\
\hline SC-6 & Resource Availability & $1.1,1.2,2.1,2.2,2.3$ \\
\hline SC-7 & Boundary Protection & $1.1,1.2,2.1,2.2,2.3$ \\
\hline SC-8 & Transmission Confidentiality and Integrity & $1.1,1.2,2.1,2.2,2.3$ \\
\hline SC-9 & Withdrawn & $N / A$ \\
\hline SC-10 & Network Disconnect & $1.1,1.2,2.1,2.2,2.3$ \\
\hline SC-11 & Trusted Path & $1.1,1.2,2.1,2.2,2.3$ \\
\hline SC-12 & $\begin{array}{l}\text { Cryptographic Key Establishment and Man- } \\
\text { agement }\end{array}$ & $1.1,1.2,2.1,2.2,2.3$ \\
\hline SC-13 & Cryptographic Protection & $1.1,1.2,2.2,2.3,4.2$ \\
\hline SC-14 & Withdrawn & $N / A$ \\
\hline SC-15 & Collaborative Computing Devices & $1.1,1.2,2.1,2.2,2.3$ \\
\hline SC-16 & Transmission of Security Attributes & $1.1,1.2,2.1,2.2,2.3$ \\
\hline SC-17 & Public Key Infrastructure Certificates & $1.1,1.2,2.1,2.2,2.3$ \\
\hline SC-18 & Mobile Code & $1.1,1.2,2.1,2.2,2.3$ \\
\hline SC-19 & Voice Over Internet Protocol & $1.1,1.2,2.1,2.2,2.3$ \\
\hline SC-20 & $\begin{array}{l}\text { Secure Name/Address Resolution Service } \\
\text { (Authoritative Source) }\end{array}$ & $1.1,1.2,2.1,2.2,2.3$ \\
\hline SC-21 & $\begin{array}{l}\text { Secure Name/Address Resolution Service } \\
\text { (Recursive or Caching Resolver) }\end{array}$ & $1.1,1.2,2.1,2.2,2.3$ \\
\hline SC-22 & $\begin{array}{l}\text { Architecture and Provisioning for } \\
\text { Name/Address Resolution Service }\end{array}$ & $1.1,1.2,2.1,2.2,2.3$ \\
\hline SC-23 & Session Authenticity & $1.1,1.2,2.1,2.2,2.3$ \\
\hline SC-24 & Fail in Known State & $1.1,1.2,2.1,2.2,2.3$ \\
\hline SC-25 & Thin Nodes & $1.1,1.2,2.1,2.2,2.3$ \\
\hline
\end{tabular}




\begin{tabular}{|c|c|c|}
\hline \multicolumn{2}{|c|}{ NIST SP 800-53 Rev. 4} & \multirow[t]{2}{*}{ Taxonomy Subclasses and Elements } \\
\hline $\begin{array}{l}\text { Control } \\
\text { Number }\end{array}$ & Control Description & \\
\hline SC-26 & Honeypots & $1.2,2.2 .4$ \\
\hline SC-27 & Platform-Independent Applications & $1.1,1.2,2.1,2.2,2.3$ \\
\hline SC-28 & Protection of Information at Rest & $1.1,1.2,2.1,2.2,2.3$ \\
\hline SC-29 & Heterogeneity & $1.1,1.2,2.1,2.2,2.3$ \\
\hline SC-30 & Concealment and Misdirection & $1.2,2.1,2.2,2.3$ \\
\hline SC-31 & Covert Channel Analysis & $1.2,2.1,2.2 .4,2.3$ \\
\hline SC-32 & Information System Partitioning & $1.1,1.2,2.1,2.2,2.3$ \\
\hline SC-33 & Withdrawn & $N / A$ \\
\hline SC-34 & Non-Modifiable Executable Programs & $1.1,1.2,2.2,2.3$ \\
\hline SC-35 & Honeyclients & $1.2,2.2 .4$ \\
\hline SC-36 & Distributed Processing and Storage & $1.1,1.2,2.1,2.2,2.3$ \\
\hline SC-37 & Out-of-Band Channels & $1.1,1.2,2.1,2.2,2.3$ \\
\hline SC-38 & Operations Security & $1.1,1.2,2.1,2.2,2.3$ \\
\hline SC-39 & Process Isolation & $1.1,1.2,2.1,2.2,2.3$ \\
\hline SC-40 & Wireless Link Protection & $1.1,1.2,2.1,2.2,2.3$ \\
\hline SC-41 & Port and I/O Device Access & $1.1,1.2,2.1,2.2,2.3$ \\
\hline SC-42 & Sensor Capability and Data & $1.1,1.2,2.1,2.2,2.3,4.2$ \\
\hline SC-43 & Usage Restrictions & $1.1,1.2,2.1,2.2,2.3$ \\
\hline SC-44 & Detonation Chambers & $1.1,1.2,2.1,2.2,2.3$ \\
\hline SI-1 & $\begin{array}{l}\text { System and Information Integrity Policy and } \\
\text { Procedures }\end{array}$ & $3.1,3.2,4.2$ \\
\hline SI-2 & Flaw Remediation & $2.2 .4,2.3,3.1,3.2$ \\
\hline SI-3 & Malicious Code Protection & $1.2,2.2 .4,2.3,3.1,3.2$ \\
\hline SI-4 & Information System Monitoring & $1.2,2.2,2.3,3.1,3.2$ \\
\hline SI-5 & Security Alerts, Advisories, and Directives & $2.2,2.3,3.1,3.2,4.2$ \\
\hline
\end{tabular}




\begin{tabular}{|c|c|c|}
\hline \multicolumn{2}{|c|}{ NIST SP 800-53 Rev. 4} & \multirow[t]{2}{*}{ Taxonomy Subclasses and Elements } \\
\hline $\begin{array}{l}\text { Control } \\
\text { Number }\end{array}$ & Control Description & \\
\hline $\mathrm{SI}-6$ & Security Function Verification & $2.2,2.3,3.1,3.2$ \\
\hline $\mathrm{SI}-7$ & $\begin{array}{l}\text { Software, Firmware, and Information Integri- } \\
\text { ty }\end{array}$ & $1.1,1.2,2.2,2.3,3.1,3.2,4.2$ \\
\hline $\mathrm{SI}-8$ & Spam Protection & $2.2,2.3,3.1,3.2$ \\
\hline SI-9 & Withdrawn & $N / A$ \\
\hline SI-10 & Information Input Validation & $1.1,1.2,2.2,2.3,3.1,3.2$ \\
\hline SI-11 & Error Handling & $1.1,1.2,2.2,2.3,3.1,3.2$ \\
\hline $\mathrm{SI}-12$ & Information Handling and Retention & $2.2,2.3,3.1,3.2,4.2$ \\
\hline $\mathrm{SI}-13$ & Predictable Failure Prevention & $2.1,2.3,3.1,3.2$ \\
\hline $\mathrm{SI}-14$ & Non-Persistence & $1.2,2.2,2.3,3.1,3.2$ \\
\hline $\mathrm{SI}-15$ & Information Output Filtering & $1.2,2.2,2.3,3.1,3.2$ \\
\hline SI-16 & Memory Protection & $1.2,2.2,2.3,3.1,3.2$ \\
\hline $\mathrm{SI}-17$ & Fail-Safe Procedures & $2.1,2.2,2.3,4.1,4.3,4.4$ \\
\hline PM-1 & Information Security Program Plan & $3.1,3.2,3.3$ \\
\hline PM-2 & Senior Information Security Officer & $3.1,3.2,3.3$ \\
\hline PM-3 & Information Security Resources & $3.1,3.2,3.3$ \\
\hline PM-4 & Plan of Action and Milestones Process & $3.1,3.2,3.3$ \\
\hline PM-5 & Information System Inventory & $3.1,3.2,3.3$ \\
\hline PM-6 & $\begin{array}{l}\text { Information Security Measures of } \\
\text { Performance }\end{array}$ & $3.1,3.2,3.3$ \\
\hline PM-7 & Enterprise Architecture & $2.2,2.3,4.2$ \\
\hline PM-8 & Critical Infrastructure Plan & $3.1,3.2,3.3$ \\
\hline PM-9 & Risk Management Strategy & $3.1,3.2,3.3$ \\
\hline PM-10 & Security Authorization Process & $3.1,3.2,3.3$ \\
\hline PM-11 & Mission/Business Process Definition & $3.1,3.2,3.3$ \\
\hline PM-12 & Insider Threat Program & $1.2,3.1,3.2,3.3$ \\
\hline
\end{tabular}




\begin{tabular}{|c|c|c|}
\hline \multicolumn{2}{|c|}{ NIST SP 800-53 Rev. 4} & \multirow[t]{2}{*}{ Taxonomy Subclasses and Elements } \\
\hline $\begin{array}{l}\text { Control } \\
\text { Number }\end{array}$ & Control Description & \\
\hline PM-13 & Information Security Workforce & $1.3,3.1,3.2,3.3$ \\
\hline PM-14 & Testing, Training, and Monitoring & $3.1,3.2,3.3$ \\
\hline PM-15 & $\begin{array}{l}\text { Contacts with Security Groups and } \\
\text { Associations }\end{array}$ & $1.1,1.2,1.3,2.2,4.2$ \\
\hline PM-16 & Threat Awareness Program & $1.2,3.1,3.2,3.3$ \\
\hline AP-1 & Authority to Collect & $3.1,4.2$ \\
\hline AP-2 & Purpose Specification & $3.1,4.2$ \\
\hline AR-1 & Governance and Privacy Program & $3.1,3.2,3.3,4.2$ \\
\hline AR-2 & Privacy Impact and Risk Assessment & $3.1,3.2,3.3,4.2$ \\
\hline AR-3 & $\begin{array}{l}\text { Privacy Requirements for Contractors and } \\
\text { Service Providers }\end{array}$ & $1.1,1.2,3.1,4.2$ \\
\hline AR-4 & Privacy Monitoring and Auditing & $3.1,3.2,4.2$ \\
\hline AR-5 & Privacy Awareness and Training & $1.3,3.1,3.2,4.2$ \\
\hline AR-6 & Privacy Reporting & $3.1,3.2,4.2$ \\
\hline AR-7 & $\begin{array}{l}\text { Privacy-Enhanced System Design and De- } \\
\text { velopment }\end{array}$ & $2.2,2.3,3.1,3.2,4.2$ \\
\hline AR-8 & Accounting of Disclosures & $3.1,4.2$ \\
\hline $\mathrm{DI}-1$ & Data Quality & $3.1,3.2,4.2$ \\
\hline $\mathrm{DI}-2$ & Data Integrity and Data Integrity Board & $3.1,3.2,4.2$ \\
\hline DM-1 & $\begin{array}{l}\text { Minimization of Personally Identifiable } \\
\text { Information }\end{array}$ & $2.3,3.1,3.2,4.2$ \\
\hline DM-2 & Data Retention and Disposal & $3.1,3.2,4.2$ \\
\hline DM-3 & $\begin{array}{l}\text { Minimization of PII Used in Testing, Train- } \\
\text { ing, and Research }\end{array}$ & $2.3,3.1,3.2,4.2$ \\
\hline IP-1 & Consent & $3.1,3.2,4.2$ \\
\hline IP-2 & Individual Access & $3.1,3.2,4.2$ \\
\hline IP-3 & Redress & $3.1,3.2,4.2$ \\
\hline
\end{tabular}




\begin{tabular}{|l|l|l|}
\hline \multicolumn{2}{|l|}{ NIST SP 800-53 Rev. 4} & \multirow{2}{*}{ Taxonomy Subclasses and Elements } \\
\cline { 1 - 2 } $\begin{array}{l}\text { Control } \\
\text { Number }\end{array}$ & Control Description & $3.1,3.2,4.2$ \\
\hline IP-4 & Complaint Management & $2.3,3.1,3.2,4.2$ \\
\hline SE-1 & $\begin{array}{l}\text { Inventory of Personally Identifiable } \\
\text { Information }\end{array}$ & $3.1,3.2,3.3,4.2$ \\
\hline SE-2 & Privacy Incident Response & 4.2 \\
\hline TR-1 & Privacy Notice & $3.1,3.2,4.2$ \\
\hline TR-2 & $\begin{array}{l}\text { System of Records Notices and Privacy Act } \\
\text { Statements }\end{array}$ & $3.1,4.2$ \\
\hline TR-3 & $\begin{array}{l}\text { Dissemination of Privacy Program } \\
\text { Information }\end{array}$ & $3.1,3.2,4.2$ \\
\hline UL-1 & Internal Use & $1.3,3.1,3.2,3.3 .3,4.2$ \\
\hline UL-2 & Information Sharing with Third Parties & \\
\hline
\end{tabular}




\section{Appendix B: Mapping of Selected Taxonomy Subclasses and Elements to NIST SP 800-53 Rev. 4 Controls}

The following table can be used to determine which NIST controls to consider in order to mitigate

a specific operational cyber security risks.

Table 3: Mapping of Taxonomy Subclasses and Elements to NIST Controls

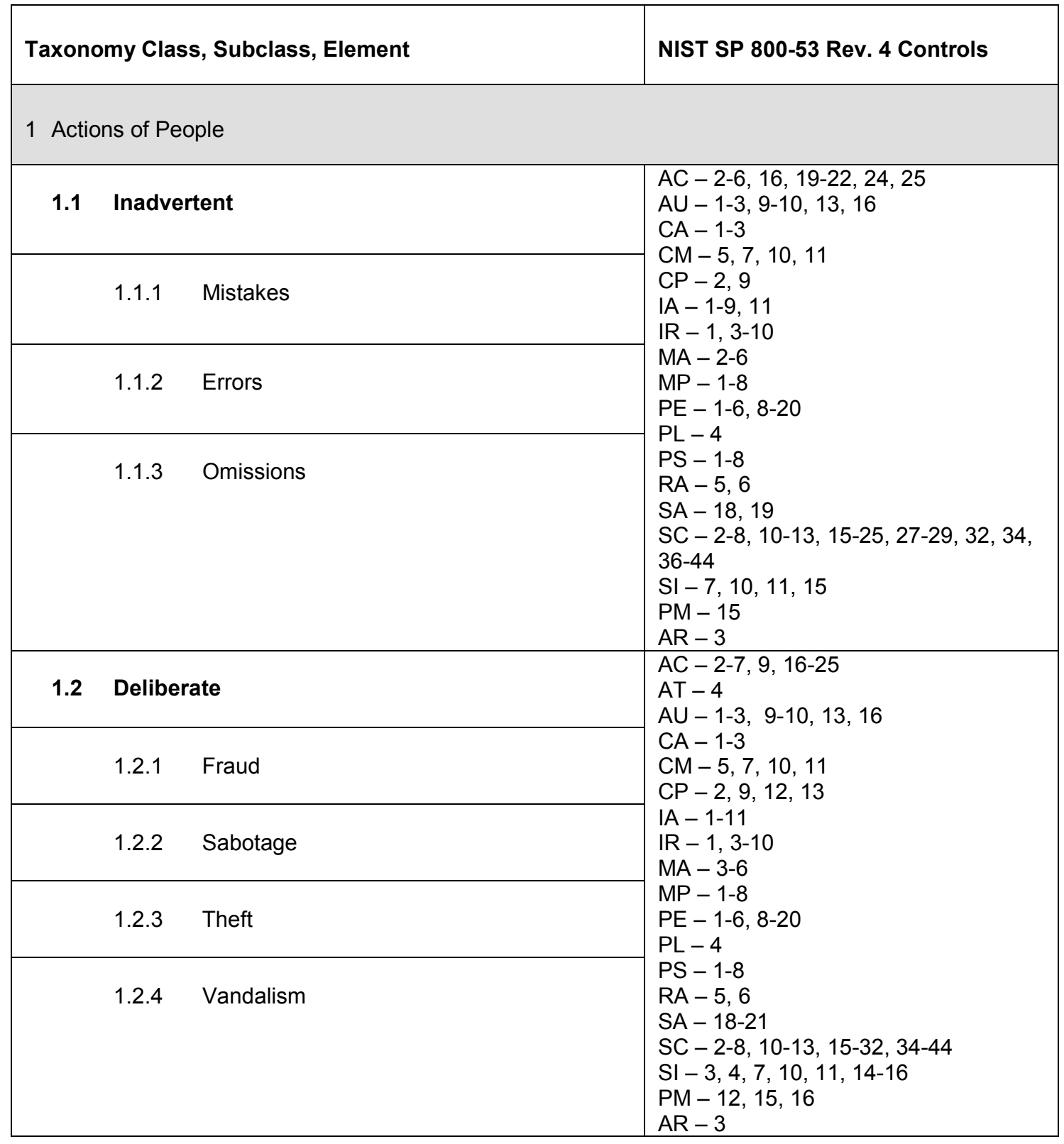




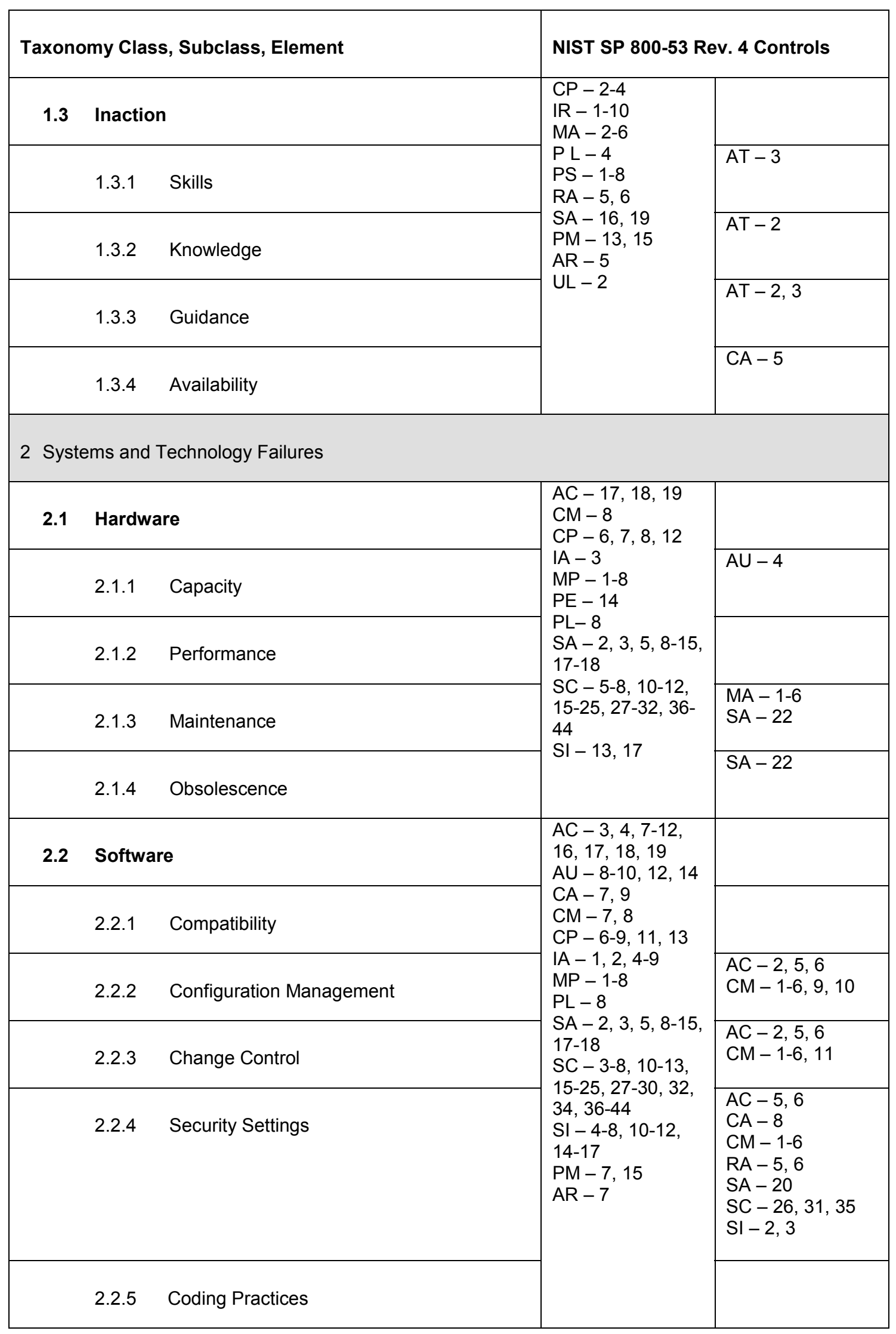




\begin{tabular}{|c|c|c|c|}
\hline \multicolumn{2}{|c|}{ Taxonomy Class, Subclass, Element } & \multicolumn{2}{|c|}{ NIST SP 800-53 Rev. 4 Controls } \\
\hline 2.2 .6 & Testing & & $\begin{array}{l}\mathrm{CA}-8 \\
\mathrm{CM}-4,5\end{array}$ \\
\hline \multicolumn{2}{|c|}{ Systems } & \multirow{5}{*}{ 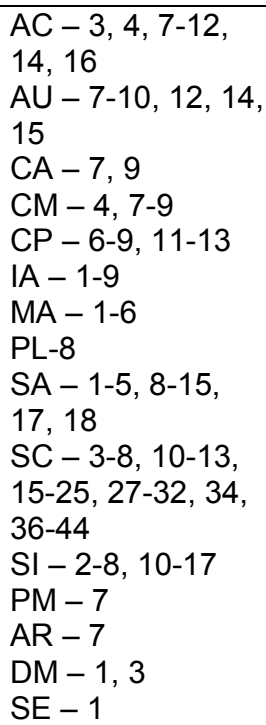 } & \\
\hline 2.3.1 & Design & & \\
\hline 2.3 .2 & Specifications & & $A C-5,6$ \\
\hline 2.3 .3 & Integration & & CA -8 \\
\hline 2.3 .4 & Complexity & & \\
\hline \multicolumn{4}{|c|}{3 Failed Internal Processes } \\
\hline 3.1 Proce & Process Design and/or Execution & \multirow{9}{*}{\multicolumn{2}{|c|}{ 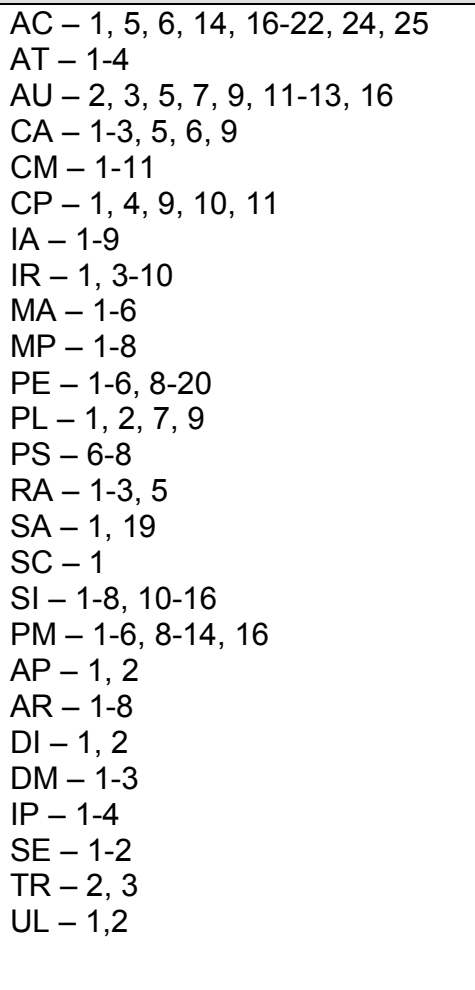 }} \\
\hline 3.1 .1 & Process Flow & & \\
\hline 3.1 .2 & Process Documentation & & \\
\hline 3.1 .3 & Roles and Responsibilities & & \\
\hline 3.1 .4 & Notifications and Alerts & & \\
\hline 3.1 .5 & Information Flow & & \\
\hline 3.1 .6 & Escalation of Issues & & \\
\hline 3.1 .7 & Service Level Agreements & & \\
\hline 3.1 .8 & Task Hand-Off & & \\
\hline
\end{tabular}




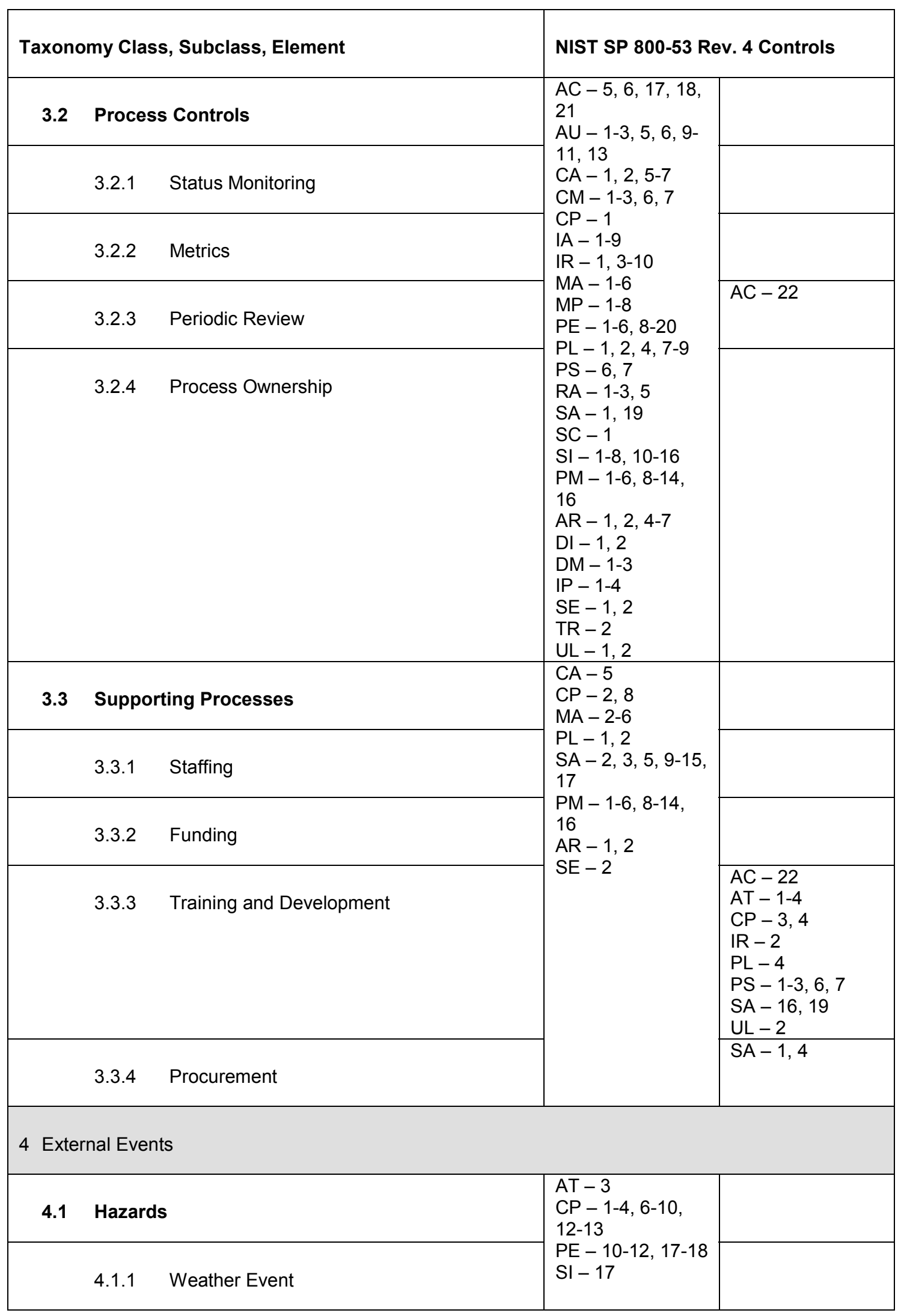




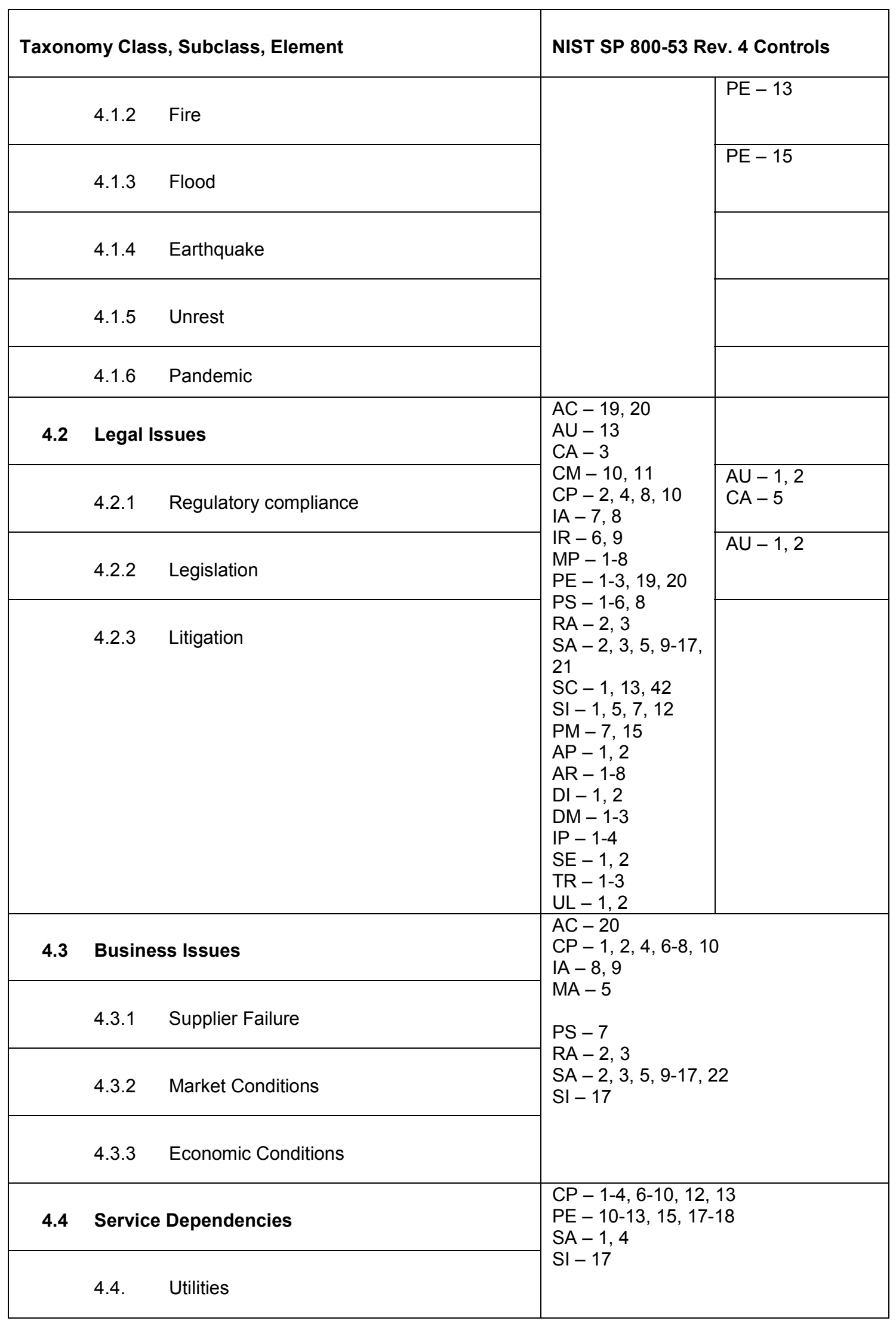




\begin{tabular}{|c|c|}
\hline Taxonomy Class, Subclass, Element & \multirow{2}{*}{ NIST SP 800-53 Rev. 4 Controls } \\
\hline $4.4 .2 \quad$ Emergency services & \\
\cline { 1 - 2 } $4.4 .3 \quad$ Fuel & \\
\hline $4.4 .4 \quad$ Transportation & \\
\hline
\end{tabular}




\section{References}

URLs are valid as of the publication date of this document.

\section{[BIS 2006]}

Bank for International Settlements (BIS). International Convergence of Capital Measurement and Capital Standards: A Revised Framework Comprehensive Version. http://www.bis.org/publ/bcbs128.pdf (2006).

\section{[Caralli 2010a]}

Caralli, Richard A.; Allen, Julia H.; Curtis, Pamela D.; White, David W.; \& Young, Lisa R. $C E R T^{\circledR}$ Resilience Management Model, v1.0 (CMU/SEI-2010-TR-012). Software Engineering Institute, Carnegie Mellon University, 2010.

http://resources.sei.cmu.edu/library/asset-view.cfm?assetID=9479

\section{[Caralli 2010b]}

Caralli, Richard A.; Allen, Julia H.; Curtis, Pamela D.; White, David W.; \& Young, Lisa R. $C E R T^{\circledR}$ Resilience Management Model, v1.0 - Risk Management (RISK). Software Engineering Institute, Carnegie Mellon University, 2010.

http://www.cert.org/resilience/products-services/cert-rmm/index.cfm

\section{[DHS 2008]}

Department of Homeland Security (DHS) Risk Steering Committee. DHS Risk Lexicon. Department of Homeland Security, September 2008.

http://www.dhs.gov/xlibrary/assets/dhs_risk_lexicon.pdf

\section{[FISMA 2002]}

Federal Information Systems Management Act of 2002, 44 U.S.C. § 3542(b)(1). Office of the Law Revision Counsel, 2002. http://uscode.house.gov

\section{[Gallagher 2005]}

Gallagher, Brian P.; Case, Pamela J.; Creel, Rita C.; Kushner, Susan; \& Williams, Ray C. A Taxonomy of Operational Risks (CMU/SEI-2005-TN-036). Software Engineering Institute, Carnegie Mellon University, 2005. http://resources.sei.cmu.edu/library/asset-view.cfm?assetID=7525

\section{[Kendall 2007]}

Kendall, Richard P.; Post, Douglass E.; Carver, Jeffrey C.; Henderson, Dale B.; \& Fisher, David A. A Proposed Taxonomy for Software Development Risks for High-Performance Computing (HPC) Scientific/Engineering Applications (CMU/SEI-2006-TN-039). Software Engineering Institute, Carnegie Mellon University, 2007.

http://resources.sei.cmu.edu/library/asset-view.cfm?assetID=8013

\section{[NIST 2013]}

National Institute of Standards and Technology (NIST). U.S. Department of Commerce. NIST Special Publication 800-53 Revision 4, Security and Privacy Controls for Federal Information Systems and Organizations. NIST, 2013. http://dx.doi.org/10.6028/NIST.SP.800-53r4 


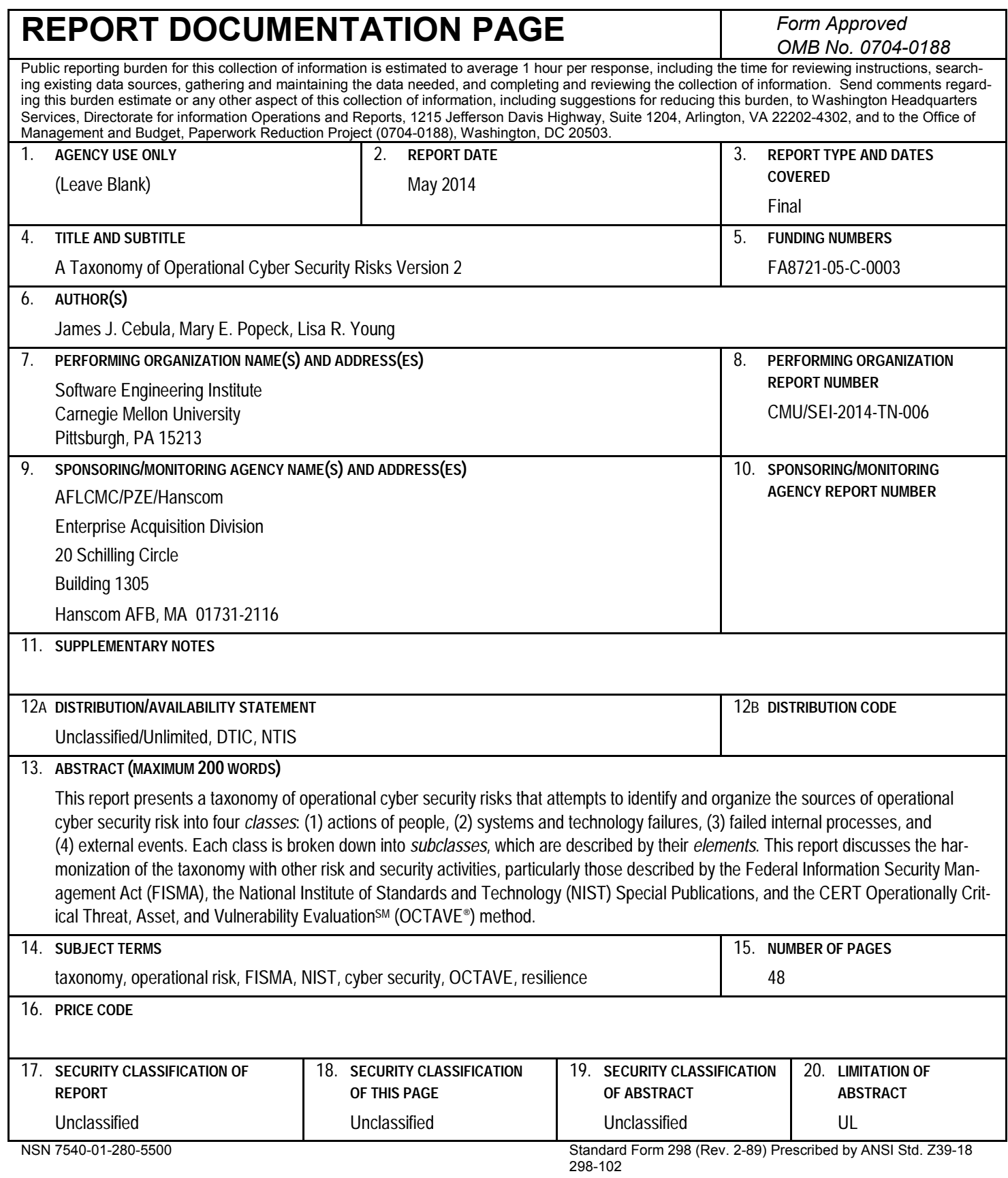

